Utah State University

DigitalCommons@USU

$1-1-2014$

\title{
Ammonia Measurements and Emissions from a California Dairy Using Point and Remote Sensors
}

\author{
K. D. Moore \\ E. Young \\ C. Gurell \\ M. D. Wojcik \\ R. S. Martin \\ G. E. Bingham
}

See next page for additional authors

Follow this and additional works at: https://digitalcommons.usu.edu/sdl_pubs

\section{Recommended Citation}

Moore, K. D.; Young, E.; Gurell, C.; Wojcik, M. D.; Martin, R. S.; Bingham, G. E.; Pfeiffer, R. L.; Prueger, J. H.; and Hatfield, J. L., "Ammonia Measurements and Emissions from a California Dairy Using Point and Remote Sensors" (2014). Space Dynamics Lab Publications. Paper 95.

https://digitalcommons.usu.edu/sdl_pubs/95

This Article is brought to you for free and open access by the Space Dynamics Lab at DigitalCommons@USU. It has been accepted for inclusion in Space Dynamics Lab Publications by an authorized administrator of DigitalCommons@USU. For more information, please contact digitalcommons@usu.edu.

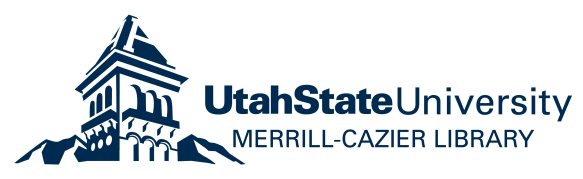




\section{Authors}

K. D. Moore, E. Young, C. Gurell, M. D. Wojcik, R. S. Martin, G. E. Bingham, R. L. Pfeiffer, J. H. Prueger, and J. L. Hatfield 


\title{
AMMONIA MEASUREMENTS AND EMISSIONS FROM A CALIFORNIA DAIRY USING POINT AND REMOTE SENSORS
}

\author{
K. D. Moore, E. Young, C. Gurell, M. D. Wojcik, R. S. Martin, \\ G. E. Bingham, R. L. Pfeiffer, J. H. Prueger, J. L. Hatfield
}

\begin{abstract}
Ammonia $\left(\mathrm{NH}_{3}\right)$ is an important trace gas species in the atmosphere that can have negative impacts on human, animal, and ecosystem health. Agriculture has been identified as the largest source of $\mathrm{NH}_{3}$, specifically livestock operations. $\mathrm{NH}_{3}$ emissions from a commercial dairy in California were investigated during June 2008. Cattle were held in open-lot pens, except for young calves in hutches with shelters. Solid manure was stored in the open-lot pens. Liquid manure from feed lanes was passed through a solids settling basin and stored in a holding pond. Passive sensors and openpath Fourier transform infrared spectrometers (OP-FTIR) were deployed around the facility to measure $\mathrm{NH}_{3}$ concentrations. Emissions from pens and the liquid manure system (LMS) were estimated using inverse modeling. Mean emission factors (EFs) for the entire facility were $140.5 \pm 42.5 \mathrm{~g} \mathrm{~d}^{-1}$ animal ${ }^{-1}$ from the passive sampler data and $199.2 \pm 22.0 \mathrm{~g} \mathrm{~d}^{-1}$ animal $^{-1}$ from the OP-FTIR data, resulting in the facility's summer emissions calculated at $265.2 \pm 80.2 \mathrm{~kg} d^{-1}$ and 375.4 $\pm 27.1 \mathrm{~kg} \mathrm{~d}^{-1}$, respectively. These EFs are within the range of values reported in the literature. Both concentrations and emissions exhibited a strong diurnal cycle, peaking in the late afternoon. Total facility emissions exhibited significant positive correlations with temperature and wind speed. The findings of this study show that $\mathrm{NH}_{3}$ emissions from a commercial dairy can vary by a factor of 10 or more throughout the day, and EFs can vary by two orders of magnitude when compared to other U.S. dairies, based on literature values.
\end{abstract}

Keywords. Air pollution, Ammonia, Dairy, Emission, Fourier transform infrared spectroscopy, Inverse modeling, Optimization, Passive sampler, Remote sensing.

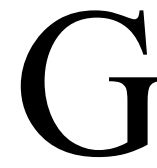
aseous ammonia $\left(\mathrm{NH}_{3}\right)$ is a significant basic species in the atmosphere and a compound of environmental concern based on two potentially major impacts. First, it may combine with nitric or sulfuric acids to form small particles that contribute to fine particulate matter (PM) concentrations, which have been shown to have adverse health effects in humans and

Submitted for review in December 2012 as manuscript number SE 10079; approved for publication by the Structures \& Environment Division of ASABE in December 2013.

Any opinions, findings, conclusions, or recommendations expressed in this publication are those of the authors and do not necessarily reflect the view of the USDA. Mention of a trademark, proprietary product, or vendor is for information purposes only and does not constitute an endorsement by the USDA, Utah State University, or Space Dynamics Laboratory. The USDA is an equal opportunity provider and employer.

The authors are Kori D. Moore, ASABE Member, Environmental Engineer and Graduate Student, Space Dynamics Laboratory, Utah State University Research Foundation, North Logan, Utah; Emyrei Young, currently Environmental Engineer, CH2M HILL, Salt Lake City, Utah; Cassi Gurell, currently Software Engineer, L3 Communication SystemsWest, Salt Lake City, Utah; Michael D. Wojcik, Senior Scientist, Space Dynamics Laboratory, Utah State University Research Foundation, North Logan, Utah; Randal S. Martin, ASABE Member, Associate Professor, Department of Civil and Environmental Engineering, Utah State University, Logan, Utah; Gail E. Bingham, Chief Scientist, Space Dynamics Laboratory, Utah State University Research Foundation, North Logan, Utah; Richard L. Pfeiffer, Chemist, John H. Prueger, Soil Scientist, and Jerry L. Hatfield, Laboratory Director, USDA-ARS National Laboratory for Agriculture and the Environment, Ames, Iowa. Corresponding author: Kori D. Moore, Space Dynamics Laboratory, 1695 North Research Park Way, North Logan, UT 84341; phone: 435-7133848; e-mail: kori.moore@sdl.usu.edu. animals and impacts on visibility and climate (Davidson et al., 2005). The second potential impact of $\mathrm{NH}_{3}$ is through deposition, either dry or wet, to the land/water surface that may significantly contribute to local nitrogen budgets, which in turn affect ecosystem health and stability (Paerl, 1985; Duce, 1991).

Ammonia is a by-product of the microbial degradation of substances containing organic nitrogen, i.e., any plant or animal material. It is also manufactured for industrial and fertilizer uses. Various emissions inventories estimate that agriculture-related activities contribute the largest portion of total $\mathrm{NH}_{3}$ emissions, with $50 \%$ to $75 \%$ from livestock production (Battye et al., 2003; EPA, 2003). Livestock feed contains nitrogen $(\mathrm{N})$ for conversion to animal product, but the utilization of that $\mathrm{N}$ is relatively inefficient: $50 \%$ to $80 \%$ of $\mathrm{N}$ intake is excreted in urea and manure. Gaseous $\mathrm{NH}_{3}$ emissions originate from the excreted material, with substantial portions of it potentially volatilized as $\mathrm{NH}_{3}$ within hours. Emission locations include animal housing, manure storage and treatment facilities, and manure land application. Many different factors have been shown to affect $\mathrm{NH}_{3}$ emissions and include, but are not limited to: $\mathrm{pH}$, temperature, wind speed, chemical and microbiological activities, total ammoniacal concentration (TAN), and transport and dispersion characteristics (Arogo et al., 2006).

Given the potential negative environmental effects of $\mathrm{NH}_{3}$ and the large contribution to total emissions from agricultural livestock operations, focus has increased on 
quantifying emission rates (ERs) and emission factors (EFs) from a variety of livestock facilities. For the purposes of this discussion, EFs are emission values on a per animal or per animal unit (AU) and per unit time basis (i.e., $\mathrm{g} \mathrm{d}^{-1}$ animal $^{-1}$ or kg year ${ }^{-1} \mathrm{AU}^{-1}$ ), while ERs are based on time but not per animal (i.e., $\mathrm{kg} \mathrm{d}^{-1}$ or $\mathrm{g} \mathrm{m}^{-2} \mathrm{~s}^{-1}$ ). This article focuses on $\mathrm{NH}_{3}$ emissions from a dairy cattle facility; dairies were estimated to contribute $24 \%$ of the total U.S. livestock $\mathrm{NH}_{3}$ emissions in 2002 (EPA, 2005). There is a wide variety of climate, feeding, housing, facility operation, and manure management conditions in the dairy industry, all of which potentially affect $\mathrm{NH}_{3}$ emissions and complicate estimating the industry's impacts on the environment. It is therefore important that emission measurements be made under as many conditions as possible. Several published studies have investigated emissions from U.S. dairies under different conditions and over varying periods of time, with estimated EFs ranging over two orders of magnitude (Schmidt et al., 2002; Cassel et al., 2005; Moore, 2007; Mukhtar et al., 2008; Rumburg et al., 2008a, 2008b; Bjorneberg et al., 2009; Flesch et al., 2009a; AdvientoBorbe et al., 2010; Leytem et al., 2010, 2013). Note that only one study, reported by Cassel et al. (2005) based on winter measurements, was conducted in California, the state with the largest milk cow population in the U.S. at $20 \%$ of the national population and with areas of significant air quality issues related to fine PM formed from $\mathrm{NH}_{3}$ (Chow et al., 1993; USDA, 2009).

In an effort to contribute to the body of knowledge on air pollutants originating from California dairies and their potential environmental impacts, a study was conducted at a commercial dairy in the San Joaquin Valley to (1) characterize $\mathrm{PM}$ and $\mathrm{NH}_{3}$ concentrations in and around the dairy using both point and remote sensors and (2) quantify summer $\mathrm{PM}$ and $\mathrm{NH}_{3}$ emissions from each source type present and from the facility as a whole. The results of the PM portion of the study have been published (Marchant et al., 2011). This article reports on the $\mathrm{NH}_{3}$ measurements and emissions calculations.

\section{MATERIALS AND MeTHODS}

Ammonia concentrations and meteorological conditions were monitored in and around a dairy operation in the San Joaquin Valley of California in June 2008. ERs and EFs were estimated using an inverse modeling technique coupled with data from two sampling techniques: passive $\mathrm{NH}_{3}$ samplers and open-path Fourier transform infrared spectroscopy (OP-FTIR). The $\mathrm{NH}_{3}$ emissions were estimated for two potential source groups, pens and a liquid manure system (LMS), and normalized by the number of animals in the facility.

\section{SITE DESCRIPTION}

The dairy is located in northern Kings County, California, and is surrounded by agricultural land. The dairy facility covers 24.7 ha, including all associated storage areas and access roads, which are mostly unpaved. A paved county road borders the dairy on the east side, with crop land on the three other sides. Milk cows, dry cows, bulls, steers, and heifers uniformly distributed between birth and two years old were all housed on the dairy during the study period. Table 1 lists the number of animals, number of AU, and the average mass in each animal category. One AU is defined as one heifer, steer, or bull cattle and 0.7 milk or dry cattle (EPA, 2001), yielding a total of 2,335 AU on this dairy with 1,885 animals. The average size of a cattle farm in Kings County in 2007 was 1,021 animals, while the average dairy had 1,169 milk cows (USDA, 2009).

The youngest calves were housed in individual small hutches, each with a shelter. Milk cows, bulls, steers, dry cows, and heifers older than about four weeks were housed in open-lot pens with a dirt base. Stocking density during this study averaged $64.1 \mathrm{~m}^{2}$ animal ${ }^{-1}$. Most open-lot pens were equipped with a canopy shelter consisting of a corrugated metal roof elevated about $6 \mathrm{~m}$ above ground level (agl) on poles. The total pen area was 13.0 ha, about $53 \%$ of the dairy footprint, with a total of 0.8 ha covered by shelters. The dairy layout is presented in figure 1, with the group of pens for each animal category labeled and the locations of feed, equipment, and manure storage locations also shown. It should be noted that the five steers occupied only a quarter of the northwestern most pen.

Table 1. Animal count, average animal mass, average feed characteristics, and estimated manure and nitrogen excreted for cattle on this dairy during the study period. Excretion values were estimated based on information provided by Nennich et al. (2005) as part of revisions to ASABE Standard D384.1 (ASABE Standards, 2005).

\begin{tabular}{|c|c|c|c|c|c|c|c|}
\hline Animal Type & $\begin{array}{c}\text { Animal } \\
\text { Count }\end{array}$ & $\begin{array}{c}\text { Animal } \\
\text { Unit } \\
(\mathrm{AU})\end{array}$ & $\begin{array}{c}\text { Average } \\
\text { Mass } \\
(\mathrm{kg})\end{array}$ & $\begin{array}{c}\text { Dry Matter } \\
\text { Intake } \\
\left(\mathrm{kg} \mathrm{d}^{-1} \text { animal }^{-1}\right)\end{array}$ & $\begin{array}{c}\text { Dietary } \\
\text { Crude Protein } \\
(\%)\end{array}$ & $\begin{array}{c}\text { Manure } \\
\text { Excreted } \\
\left(\mathrm{kg} \mathrm{d}^{-1} \text { animal }^{-1}\right)\end{array}$ & $\begin{array}{c}\text { Nitrogen } \\
\text { Excreted } \\
\left(\mathrm{kg} \mathrm{N} \mathrm{d}^{-1} \text { animal }^{-1}\right)\end{array}$ \\
\hline Milk cow & 950 & 1,357 & 748 & 25.2 & 18.4 & 75.7 & 0.537 \\
\hline Dry cow & 100 & 143 & 748 & 14.8 & 17 & 49.8 & 0.334 \\
\hline Bull $^{[\mathrm{a}]}$ & 30 & 30 & 857 & 14.8 & 17.7 & 49.8 & 0.353 \\
\hline Heifer & 740 & 740 & - & - & - & - & - \\
\hline Large (1 to 2 years old) & 400 & 400 & 435 & 10.1 & 17 & 31.3 & 0.186 \\
\hline Small $(<1$ year old $)$ & 340 & 340 & 195 & 8.9 & 17 & 32.4 & 0.170 \\
\hline Steer ${ }^{[b]}$ & 5 & 5 & 435 & 10.1 & 17 & 31.3 & 0.186 \\
\hline Calf & 60 & 60 & 64 & 4.8 & 17 & 16.4 & 0.091 \\
\hline Farm total & 1,885 & 2,335 & NA & $33,308 \mathrm{~kg} \mathrm{~d}^{-1}$ & NA & $103,103 \mathrm{~kg} \mathrm{~d}^{-1}$ & $693 \mathrm{~kg} \mathrm{~d}^{-1}$ \\
\hline
\end{tabular}




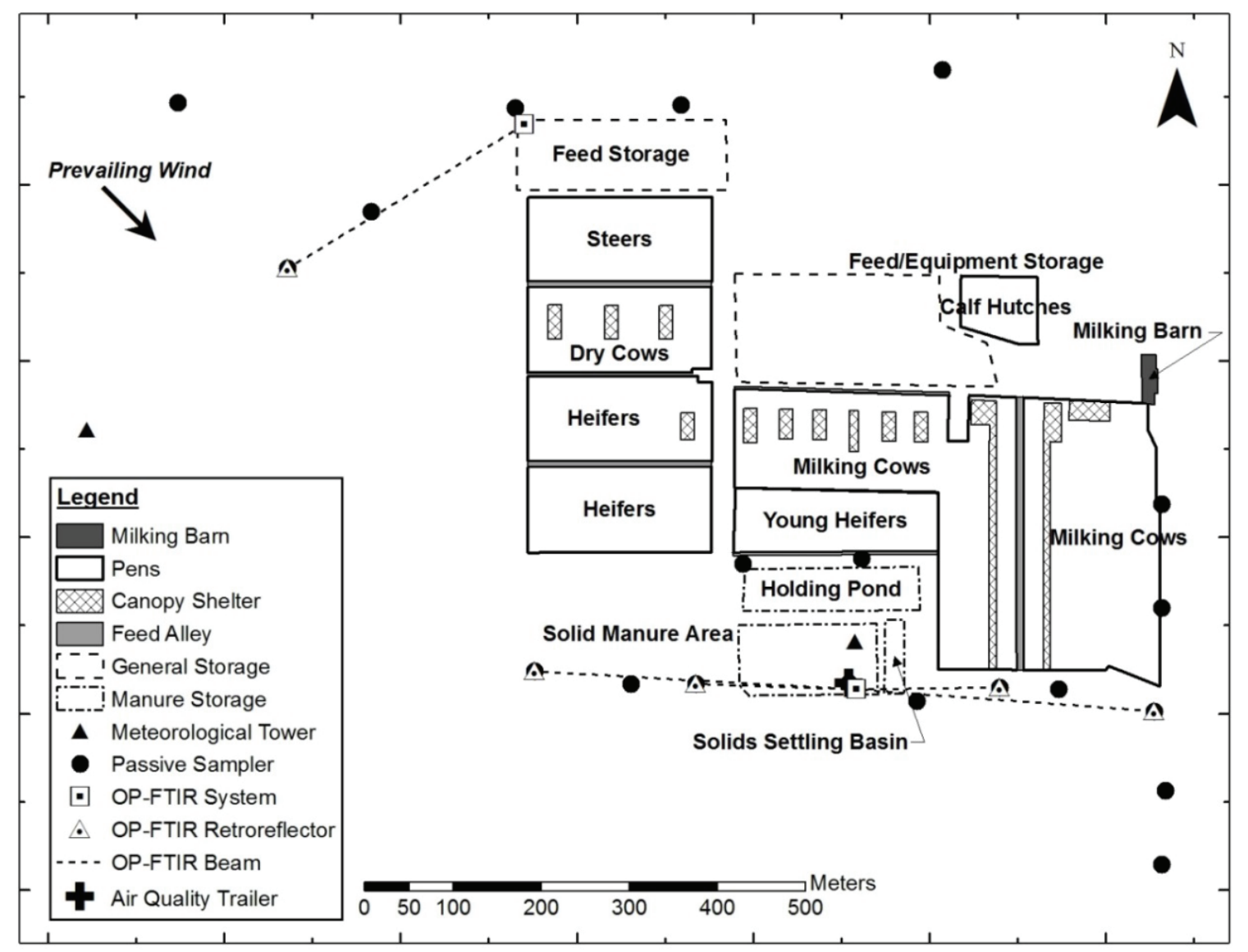

Figure 1. Map of dairy pens, storage, and sampling locations.

The cows were milked twice a day, with a milking schedule from $08: 00 \mathrm{~h}$ to $17: 00 \mathrm{~h}$ and from $20: 00 \mathrm{~h}$ to 05:00 h local time. Milk production averaged $34.1 \mathrm{~kg} \mathrm{~d}^{-1}$ animal $^{-1}$ during June 2008. A feed truck delivered feed to all pens from $05: 30 \mathrm{~h}$ to $12: 00$ noon and from 15:00 $\mathrm{h}$ to 17:00 $\mathrm{h}$ local time along concrete feed alleys adjacent to the pens. Feed lanes, areas where the cattle stand while feeding and along which cattle are moved, were concrete and sloped for drainage. The remaining pen surfaces were unpaved. Feed lanes in pens holding milk cows were flushed several times per day, while feed lanes in the other open lots were scraped on a weekly basis with one scraping occurring during this study on 18 June. Unpaved pen surfaces were scraped on an as-needed basis; corral scraping occurred during equipment setup but not during the measurement period. Manure gathered from both the feed lane and pen area was stored in each pen for later removal. The liquids generated from both milk parlor washing and milk cow feed lane flushing were first passed through an earthen solids settling basin ( $0.1 \mathrm{ha})$ and then stored in an earthen holding pond (0.6 ha). Separated solid manure was stored in windrows. The windrows present at the time of the study were in the southwest area of the solid manure handling area and were dry at the surface. These windrows were not disturbed during the measurement period, nor were solids removed from the separator basin and windrowed.

Animal diets have been shown to be a significant factor in $\mathrm{NH}_{3}$ emissions (Smits et al., 1995; Cole et al., 2005). As this study examined $\mathrm{NH}_{3}$ emissions from all cattle on the dairy, the diets for each animal type should be considered. Cattle were fed different mixed-ration diets based on gender, age, and milking status, although all diets were based on alfalfa and silage (green wheat silage for all animal types, with milk cows receiving corn silage as well) with additives to meet energy and nutrient targets. Dry matter (DM) intake and dietary crude protein (CP) content for each animal category are listed in table 1 . Milk cow DM and $\mathrm{CP}$ averaged higher than all others at $25.2 \mathrm{~kg} \mathrm{~d}^{-1}$ ani$\mathrm{mal}^{-1}$ and $18.4 \%$, respectively, while CP for all others averaged $17 \%$. Manure excreted $\left(M_{E}\right)$ and nitrogen excreted $\left(N_{E}\right)$ were estimated per animal based on equations for different categories of dairy cattle developed by Nennich et al. (2005) as part of revisions to ASABE Standard D384.1 (ASABE Standards, 2005) and summed over all cattle on the facility, as shown in table 1. Due to a small dataset, Nennich et al. (2005) did not provide equations for dry cows. It is unlikely that the average excretion values provided by Nennich et al. (2005) would be representative for this dairy since the average DM and CP for dry cows at this dairy were $43 \%$ and $28 \%$ greater, respectively, than the mean values reported by Nennich et al. (2005), although less than the maximum values reported. Therefore, $M_{E}$ and $N_{E}$ were calculated based on linear fits to the reported mean, minimum, and maximum values for $M_{E}$ and $N_{E}$ against the mean, minimum, and maximum values of DM and $\mathrm{CP}$, respectively, resulting in the following equations: 


$$
\begin{gathered}
M_{E}=2.78 \times \mathrm{DM}+8.63 \quad\left(\mathrm{R}^{2}=0.9967\right) \\
N_{E}=2.82 \times \mathrm{CP}+0.15 \quad\left(\mathrm{R}^{2}=1.000\right)
\end{gathered}
$$

$M_{E}$ and DM have units of $\mathrm{kg} \mathrm{d}^{-1}$ animal ${ }^{-1}, N_{E}$ has units of

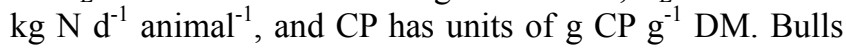
were assumed to have similar DM intake and $M_{E}$ and $N_{E}$ excretion rates as dry cows, but with an average CP of $17.7 \%$ based on the assumption that bulls were evenly divided between pens with milk cows and older heifers. Steers were assumed to have intake and excretion rates equal to the larger heifers. All of the dry dietary components were stored in the feed storage area in the northern portion of the dairy.

In order to meet $\mathrm{PM}_{10}$ emissions reductions required to bring the San Joaquin Valley into compliance with $\mathrm{PM}_{10}$ National Ambient Air Quality Standards, the San Joaquin Valley Air Pollution Control District (SJVAPCD) directed agricultural facilities above a threshold size to select and implement Conservation Management Practices (CMPs) designed to reduce $\mathrm{PM}_{10}$ emissions (Siong and Sheikh, 2006). The SJVAPCD-accepted CMP plan for this dairy operation consisted of the following management practices: (1) manure from open corrals shall be frequently scraped and/or removed, (2) pull-type manure harvesting equipment shall be used, (3) shaded areas shall be provided for cattle in open corrals, (4) wet material shall be placed in the feed wagon prior to mixing, and (5) feed shall be wetted during mixing. While these practices target the reduction of direct $\mathrm{PM}_{10}$ emissions, potential positive or negative impacts on $\mathrm{NH}_{3}$ emissions may occur. For example, frequent scraping and/or removal of manure in open corrals may produce short bursts of $\mathrm{NH}_{3}$ releases due to the manure disturbance. Shaded areas provided for cattle may affect cattle behavior and result in greater inhomogeneity in excretion deposition across the pen surface. The CMPs dealing with feed mixing and manure harvesting equipment type are not expected to affect $\mathrm{NH}_{3}$ emissions.

\section{INSTRUMENTATION}

Historical wind measurements from June 2005-2007 were obtained from station 15 of the California Irrigation Management and Information System (CIMIS) near Stratford, California, as a representative site. These records showed that wind conditions during the month of June were very consistent, with winds coming dominantly from the northwest quadrant. Instruments were deployed to measure background concentrations north and northwest of the facility and emission plumes south and southeast of the dairy (fig. 1). On-site measurements of wind direction during the experiment confirmed the dominant wind direction to be from the northwest. An air quality instrumentation trailer (dimensions approximately $5 \mathrm{~m} \times 2.5 \mathrm{~m} \times 2.5 \mathrm{~m}$ ), located near the downwind OP-FTIR unit, as shown in figure 1, was used for sample preparation, collection, and storage as well as data storage.

Two $15.3 \mathrm{~m}$ towers were erected at the site to hold meteorological instruments. One was located $400 \mathrm{~m}$ west of the dairy, and the other was located just inside the southern boundary of the dairy. Each tower was equipped with five cup anemometers mounted at heights of 2.5, 3.9, 6.2, 9.7, and $15.3 \mathrm{~m}$ agl and five temperature and relative humidity sensors at heights of $1.0,2.5,3.9,6.2$, and $8.2 \mathrm{~m}$ agl. A wind vane was positioned on top of the towers at $15.3 \mathrm{~m}$. Campbell Scientific (Logan, Utah) data loggers were used to record and store the data from instruments on the towers as 1 min averages. Incoming solar radiation, temperature, relative humidity, barometric pressure, precipitation, wind speed, and wind direction were measured and reported as 5 min averages by a weather station at $5.0 \mathrm{~m}$ agl at the air quality trailer near the downwind $15.3 \mathrm{~m}$ tower. Details of the meteorological instruments used in this study are presented in table 2. Reported meteorological values and hourly averaged data used for modeling were taken from measurements made downwind of the dairy. Due to an error discovered during post-analysis in the wind direction averaging procedure for the wind vanes on the towers, wind directions reported by the weather station were used in all calculations and modeling.

Ammonia concentrations were measured with two methods. The first method was passive absorption onto citric acid-coated filters using passive samplers and precoated filters from Ogawa USA, Inc. (Pompano Beach, Fla.). In-depth descriptions of the sampler, the $\mathrm{NH}_{3}$ concentration calculation procedure, and results from comparisons with an $\mathrm{NH}_{3}$ scrubber during collocated deployments in ambient air and inside a poultry production house are provided by Roadman et al. (2003). Collection of $\mathrm{NH}_{3}$ onto the pad is driven by a concentration gradient between the ambient air and the filter surface; the concentration at the filter

\begin{tabular}{|c|c|c|c|}
\hline Instrument & Company and Location & Parameter Measured & Accuracy \\
\hline $\begin{array}{l}\text { Gill three-cup } \\
\text { anemometer }\end{array}$ & $\begin{array}{l}\text { R.M. Young Co., } \\
\text { Traverse City, Mich. }\end{array}$ & Wind speed & $\pm 0.2 \mathrm{~m} \mathrm{~s}^{-1}$ over $1 \mathrm{~m} \mathrm{~s}^{-1}$, threshold speed $0.5 \mathrm{~m} \mathrm{~s}^{-1}$ \\
\hline \multirow{2}{*}{$\begin{array}{l}\text { HMP45C temperature } \\
\text { and } \mathrm{RH} \text { probe }\end{array}$} & \multirow{2}{*}{$\begin{array}{c}\text { Vaisala, } \\
\text { Oulu, Finland }\end{array}$} & Temperature & $\pm 0.2^{\circ} \mathrm{C}$ at $20^{\circ} \mathrm{C}$ \\
\hline & & Relative humidity & $\pm 2 \%$ for values of $0 \%$ to $90 \%, \pm 3 \%$ for values of $90 \%$ to $100 \%$ \\
\hline 024A wind vane & $\begin{array}{l}\text { Met One Instruments, } \\
\text { Grants Pass, Ore. }\end{array}$ & Wind direction & $\pm 5^{\circ}$ \\
\hline \multirow{7}{*}{$\begin{array}{c}\text { Pro2 Plus } \\
\text { weather station }\end{array}$} & \multirow{7}{*}{$\begin{array}{l}\text { Davis Instruments, } \\
\text { Hayward, Cal. }\end{array}$} & Temperature & $\pm 0.5^{\circ} \mathrm{C}$ for values $>-7^{\circ} \mathrm{C}, \pm 1.0^{\circ} \mathrm{C}$ for values $<-7^{\circ} \mathrm{C}$ \\
\hline & & Relative humidity & $\pm 3 \%$ for values of $0 \%$ to $90 \%, \pm 4 \%$ for values of $90 \%$ to $100 \%$ \\
\hline & & Solar radiation & $\pm 5 \%$ of full scale \\
\hline & & Precipitation & $\pm 3 \%$ or $0.02 \mathrm{~mm}$ per event, whichever is greater \\
\hline & & Barometric pressure & $\pm 0.8 \mathrm{~mm} \mathrm{Hg}$ at $25^{\circ} \mathrm{C}$ \\
\hline & & Wind speed & $\pm 1 \mathrm{~m} \mathrm{~s}^{-1}$ or $5 \%$, whichever is greater \\
\hline & & Wind direction & $\pm 3^{\circ}$ \\
\hline
\end{tabular}

Table 2. Meteorological instruments employed in this study. 
surface is maintained at zero due to its reaction with the acid-coated filter surface and formation of a stable compound (ammonium citrate) for subsequent analysis. Total sorption of $\mathrm{NH}_{3}$ is determined by the ambient concentration, the exposure time, and the mass transfer coefficient. Calculated concentrations represent the average concentration over the period of exposure. Roadman et al. (2003) conducted two saturation and deployment time studies and found that the diffusion and sorption of $\mathrm{NH}_{3}$ on the pad is linear for total collected masses up to $12.1 \mu \mathrm{g}$ of $\mathrm{NH}_{3}$, after which the mass transfer coefficient decreases with increasing mass collected. In cases where the total mass collected exceeded the $12.1 \mu \mathrm{g}$ threshold, the estimated concentration would be lower than the actual average concentration.

The passive sampler exposure time selected for this study was $12 \mathrm{~h}$ based on the optimum time ranges (see fig. 2 in Roadman et al., 2003) for background concentrations assumed to be close to zero and instantaneous samples of up to 2 ppm during active pumping into the solids separator basin and taken immediately downwind of the basin with a handheld $\mathrm{NH}_{3}$ gas sensor (Toxi Pro Biosystems, Middleton, Conn.; 0 to 100 ppm range, 1 ppm resolution). Passive sampler sites were arrayed upwind, downwind, and inside the dairy area, as shown by the filled circles in figure 1. Six were established as upwind sites and located to the north and northwest of the dairy with measurement heights of 1 to $2 \mathrm{~m}$ agl. The remaining 17 sites were placed at downwind locations, based on the prevailing winds, along the southern dairy border, the eastern dairy border, and between the pens with young heifers and the holding pond. Fourteen of the downwind sites sampled at 1 to $2 \mathrm{~m}$ agl heights, and three were set at $9 \mathrm{~m} \mathrm{agl}$ on towers at both ends of the southern dairy border and adjacent to the air quality trailer. Note that passive samplers were located at both $2 \mathrm{~m}$ and $9 \mathrm{~m}$ on the towers, leading to $23 \mathrm{de}-$ ployed samplers and 20 sites shown in figure 1.

Analysis of the mass of $\mathrm{NH}_{3}$ collected on the pads as ammonium $\left(\mathrm{NH}_{4}^{+}\right)$was performed within the 28-day manufacturer-suggested period of time after exposure. It was accomplished via extraction through sonication in $8 \mathrm{~mL}$ deionized water and quantification via ion chromatography (IC) at the Utah Water Research Laboratory (UWRL) in Logan, Utah. The IC instrument (Dionex Corp., Sunnyvale, Cal.) was equipped with an AS40 automated sampler, CE20 conductivity detector, GP40 gradient pump, membrane suppressor, LC chromatography oven, IonPac CS12A cation column, CG12A cation guard column, and a $500 \mu \mathrm{L}$ sample loop. The IC method used a $0.03 \mathrm{~N}$ sulfuric acid $\left(\mathrm{H}_{2} \mathrm{SO}_{4}\right)$ solution as eluent. Chemical standards, blanks, and continuous calibration verification (CCV) standards utilized de-ionized water and reagent-grade chemical stocks. Blanks and CCVs were analyzed every ten samples. Lab and field blanks were collected for each sample period and analyzed in the same manner. The mass of $\mathrm{NH}_{3}$ collected per sample and used to determine the period average concentration was calculated as the total detected mass minus the average mass detected on the corresponding lab and field blanks. Duplicate analyses were run on $9 \%$ of the samples, with the two concentration values averaged for further calculations. The average differences between duplicate analyses, expressed as the percent of the average value, was $1.4 \%$, and the median was $0.0 \%$. The average $\mathrm{MDL} \pm 1 \sigma$ for the $12 \mathrm{~h}$ sample periods was $11.4 \pm 0.4 \mathrm{ppbv}$ $\left(7.8 \pm 0.4 \mu \mathrm{g} \mathrm{m}^{-3}\right)$.

OP-FTIR was the second method of measuring ambient $\mathrm{NH}_{3}$ concentrations utilized at the dairy. OP-FTIR is a realtime monitoring technique for remote detection and quantification of multiple compounds simultaneously. The principle of operation is based on the absorption of energy at different wavelengths by different compounds. The OP-

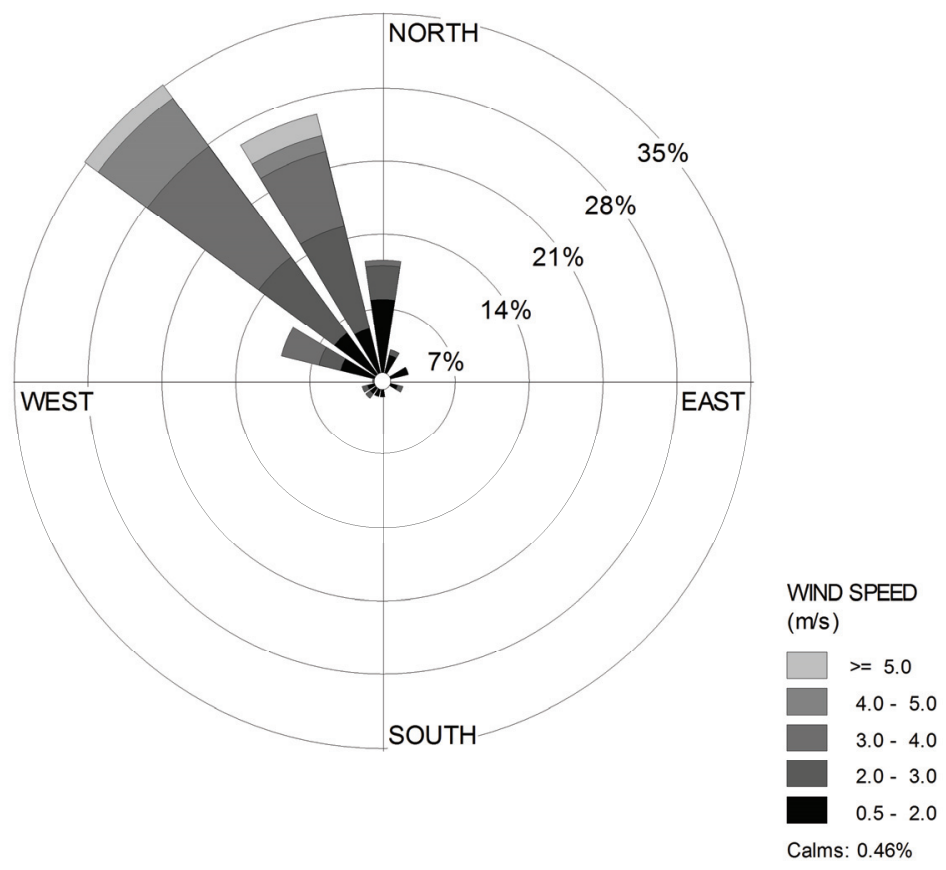

Figure 2. Hourly average wind conditions measured at the dairy during the measurement periods, 13-20 June 2008. 
FTIR unit projects an infrared (IR) beam of light through a volume to be analyzed and then captures this beam, generating a full infrared spectrum that can be used in conjunction with reference spectra to identify the gases present and allows for their concentration to be measured to ppb levels.

For this study, two OP-FTIR instruments were employed, with one located on each of the dominantly upwind and downwind sides. The upwind OP-FTIR instrument, manufactured by Industrial Monitoring and Control Corporation (IMACC, Round Rock, Texas), was operated in a monostatic mode in which a single unit containing the IR beam source, detector, and associated optics was used at one end of the path and a passive corner-cube array retroreflecting mirror was at the other end. The instrument consisted of a $0.125 \mathrm{~cm}^{-1}$ FTIR modulator, a zinc selenium beam splitter, a mercury cadmium telluride detector cooled with liquid nitrogen, a helium neon laser for dynamic alignment control, and a $25 \mathrm{~cm}$ diameter Cassegrain telescope. The upwind measurement path was $2 \mathrm{~m}$ agl along a transect from the northwest corner of the dairy over a field and totaling $250 \mathrm{~m}$ (fig. 1).

Spectra were collected at 1,3 , and 5 min intervals and analyzed using the IMACC FTIR Software Suite (ver. 01/2005). The IMACC software was used to define an analytical method for the selected analyte that was applied to each spectra to: (1) perform a point-by-point comparison with reference spectra to determine the spectral line shift required to obtain the maximum correlation coefficient; (2) select portions of the spectra for further analysis that contain minimal impacts from compounds with potential interferences, based on comparisons between the collected spectra and reference spectra for potentially interfering compounds; (3) account for background levels of other compounds and dynamic changes in the measurement environment; and (4) calculate the path length concentration of the analyte of interest through a calibration equation that accounts for response non-linearity over the full range of analyte concentrations through a best fit curve fitted to reference standard measurements across the full range. Background spectra were collected on-site during times the system was upwind of the dairy using a $25 \mathrm{~m}$ path length to minimize $\mathrm{NH}_{3}$ absorption. The algorithm developed for $\mathrm{NH}_{3}$ was applied to each recorded transmission spectra to generate a quantitative value of $\mathrm{NH}_{3}$ concentration.

The OP-FTIR on the downwind side of the dairy was a monostatic unit manufactured by MDA (Atlanta, Ga., now Cerex Monitoring Solutions, LLC, Atlanta, Ga.) that utilized a Bomem Michelson 100 interferometer, a $25 \mathrm{~cm}$ telescope, and a mercury cadmium telluride detector cooled by a Stirling engine. Spectra were collected every $70 \mathrm{~s}$. This OP-FTIR was set in a scanning system with multiple retroreflectors in order to determine $\mathrm{NH}_{3}$ concentrations along multiple lines. The scanning system consisted of a covered set of scaffolding, a rack upon which the OP-FTIR was positioned with the output beam directed vertically through a hole in the roof and then onto a mirror capable of rotational $\left(270^{\circ}\right)$ and elevational $\left(-5^{\circ}\right.$ to $+45^{\circ}$ from horizontal) movement. The mirror height was approximately $2.5 \mathrm{~m}$ agl. The IR beam was pointed toward each of six retroreflectors along the downwind side of the dairy using the steering mirror, with the OP-FTIR centrally located on the southern border of the facility, as shown in figure 1. Retroreflectors were located at about $140 \mathrm{~m}$ and $290 \mathrm{~m}$ away from the FTIR along an east-west line, with far retroreflectors stationed at both 2 to $3 \mathrm{~m}$ agl and $9 \mathrm{~m}$ agl and near retroreflectors at 2 to $3 \mathrm{~m}$ agl. Six spectra were collected at each position, with the first two spectra not used due to interference from movement of the mirror between positions and to allow system stabilization. Therefore, four consecutive $70 \mathrm{~s}$ spectra were collected along each beam path on a 42 min cycle. Return signal strength, expressed as a percent of the outgoing signal, varied between $50 \%$ and $15 \%$, depending on path length, alignment, and retroreflector cleanliness. Retroreflectors were cleaned every two to three days as needed. Spectra analysis and quantification of the path length averaged $\mathrm{NH}_{3}$ concentrations were performed using data analysis software created by Dr. Peter Griffiths at the University of Idaho utilizing a partial least squares regression technique (Griffiths et al., 2009; Shao et al., 2010) with instrument-specific calibration parameters.

During the setup period, the OP-FTIR units were placed adjacent to each other at the upwind OP-FTIR location for a collocated comparison test using adjacent beam paths. Two tests were conducted, each 1.5 to $2.0 \mathrm{~h}$ in duration. The units measured incoming background levels during one test, averaging ( \pm SD) $39.0 \pm 7.7 \mathrm{ppb}$ and $35.7 \pm 4.7 \mathrm{ppb}$ for the upwind and downwind units, respectively. Incoming background levels were spiked by exposed liquid ammonium for the other test, resulting in average concentrations of $120.3 \pm 28.8 \mathrm{ppb}$ and $121.1 \pm 23.5 \mathrm{ppb}$ for the upwind and downwind units, respectively. These tests show that the units agreed very well at the higher level and slightly less well at the lower background level.

\section{DATA TREaTment AND Filtering}

Concentrations measured by the OP-FTIR instruments were averaged over $2 \mathrm{~h}$ intervals throughout the measurement period for EF estimation. This averaging time was selected to minimize the smoothing of potential trends in emissions while providing two or more groups of samples on which to base a period average. Due to the low cumulative sampling of the downwind scanning system along a given path (approx. $4.5 \mathrm{~min}$ every $42 \mathrm{~min}$ ), the representativeness of an average value for the entire $2 \mathrm{~h}$ period was of concern. Representativeness was assessed based on a period's relative standard deviation (RSD). Exclusion of data due to RSD levels greater than $25 \%, 33 \%, 40 \%, 50 \%$, and $75 \%$ was examined. Average values with an RSD greater than $33 \%$ were excluded from EF calculations because the $33 \%$ level provided a conservative assessment of representativeness. This resulted in the removal of $\leq 30 \%$ of the averaged data in six of the seven employed OP-FTIR measurement paths from emissions calculations.

As previously stated, the sampler layout during this experiment was designed to measure the dairy facility's impact on downwind concentrations to the south and east. However, winds from directions other than the prevailing northwest sector would diminish the effectiveness of this setup. Dairy and sample layout geometry indicated that 
periods with wind directions outside of -70 to $+50^{\circ}$ from north should be excluded from the EF calculations. Hourly averaged wind direction measured on-site was used to screen data periods. While wind direction may vary considerably over an hour and render the hourly averaged wind direction insufficient for screening purposes, the wind directions recorded during this study were very consistent over time spans of several hours, with periods of higher variability almost always resulting in hourly averages outside of the optimal range. Therefore, hourly averaged wind direction values were sufficient for screening in this instance. Additionally, determination of the upwind or downwind status of each sample location/path was made based on hourly averaged wind direction.

Values reported at upwind sites were averaged to calculate the background $\mathrm{NH}_{3}$ levels $\left(C_{B}\right)$ entering the facility. Concentrations resulting from the dairy activities $\left(C_{\text {meas }}\right)$ were calculated on a location-by-location basis by subtracting $C_{B}$ from the measured downwind concentration. This difference was determined to be significant if $C_{\text {meas }}$ was greater than the $67 \%$ confidence interval (CI) about $C_{B}$, corresponding to one $\mathrm{SD}$. Only $C_{\text {meas }}$ values found to be significant in this way were used in emissions calculations. About $18 \%$ of the downwind OP-FTIR measurements lacked a corresponding OP-FTIR $C_{B}$ value. In these cases, the average passive sampler $C_{B}$ and corresponding $67 \% \mathrm{CI}$ were used to estimate $C_{\text {meas }}$.

\section{EMissions Calculations}

A dispersion model requires a user-input emission rate for a source in order to predict downwind concentration values. However, this study seeks to determine the dairy emission rate that resulted in the measured impact on downwind $\mathrm{NH}_{3}$ concentrations. This was accomplished through inverse modeling, a process of comparing a measured impact on concentration $\left(C_{\text {meas }}\right)$ at a downwind site with a model-predicted impact on concentration $\left(C_{\text {sim }}\right)$ based on an initial emission rate supplied to the model $\left(Q_{\text {sim }}\right)$ in order to estimate the actual emission rate $\left(Q_{\text {meas }}\right)$. As given by Faulkner et al. (2007) and Flesch et al. (2009b), the relationship for deriving $Q_{\text {meas }}$ from a single source, assuming a proportionally linear response between $Q_{s i m}$ and $C_{s i m}$ in the model, may be mathematically expressed as:

$$
Q_{\text {meas }}=\frac{C_{\text {meas }}}{(C / Q)_{\text {sim }}}
$$

Note that the ratio of $(C / Q)_{s i m}$ is dependent on both the source-receptor spatial relationship and the meteorological conditions over the modeled period and therefore is valid only for the modeled scenario.

When multiple sources are active and additive properties between the impacts of the different sources on the total concentration at a given location may be assumed, the multi-source inverse modeling technique described by Flesch et al. (2009b) may be used to simultaneously estimate the emissions from each source. In summary, a system of linear algebraic equations is created to estimate the emission rate of each source $i$ by calculating the modeled proportional impact on the total predicted concentration at each receptor $j$. A system of linear equations with three sources and three measurements is given in equation 4 as an example, with number subscripts representing different sources and letter subscripts representing different measurement/receptor locations:

$$
\begin{aligned}
& {\left[\begin{array}{lll}
\left(C_{A, 1} / Q_{1}\right)_{\text {sim }} & \left(C_{A, 2} / Q_{2}\right)_{\text {sim }} & \left(C_{A, 3} / Q_{3}\right)_{s i m} \\
\left(C_{B, 1} / Q_{1}\right)_{\operatorname{sim}} & \left(C_{B, 2} / Q_{2}\right)_{\text {sim }} & \left(C_{B, 3} / Q_{3}\right)_{s i m} \\
\left(C_{C, 1} / Q_{1}\right)_{\text {sim }} & \left(C_{C, 2} / Q_{2}\right)_{\operatorname{sim}} & \left(C_{C, 3} / Q_{3}\right)_{\text {sim }}
\end{array}\right]} \\
& \times\left[\begin{array}{l}
Q_{\text {meas }, 1} \\
Q_{\text {meas }, 2} \\
Q_{\text {meas }, 3}
\end{array}\right]=\left[\begin{array}{l}
C_{\text {meas }, A} \\
C_{\text {meas }, B} \\
C_{\text {meas }, C}
\end{array}\right]
\end{aligned}
$$

If there are fewer measurements than sources $(j<i)$, the system is under-determined and a unique solution cannot be found. If more measurements exist than contributing sources $(j>i)$, the system is over-determined and the solution may be found through an optimization approach. See Flesch et al. (2009b) for a more detailed description, as well as a discussion on the effect of source-receptor spatial relationships on emission estimates.

There are a variety of atmospheric dispersion models available for use in inverse modeling. The one selected to carry out this inverse modeling exercise was the American Meteorological Society/U.S. EPA Regulatory Model (AERMOD) software, executable file version 12345. It was chosen because it is a current EPA-recommended regulatory model, because it has a proportionally linear relationship between $Q_{\text {sim }}$ and $C_{\text {sim }}$ (Cimorelli et al., 2005), and to maintain continuity within the study (Marchant et al., 2011). Some recent agricultural $\mathrm{NH}_{3}$ emissions studies utilizing an inverse modeling methodology have used WindTrax (Thunder Beach Scientific, www.thunderbeachscientific. com), a backward Lagrangian stochastic model (Bjorneberg et al., 2009; Flesch et al., 2009a; Todd et al., 2008; Leytem et al., 2010, 2013). Faulkner et al. (2008) utilized both AERMOD and WindTrax, in addition to two other air dispersion models, to estimate $\mathrm{NH}_{3}$ emissions from a beef cattle feedyard. They found that ERs and EFs were model specific and that a simple relationship did not exist between the estimated emissions. However, Bonifacio et al. (2013) found strong linear correlations between AERMOD and WindTrax in estimating PM emissions from a beef cattle feedyard and calculated AERMOD/WindTrax conversion factors ranging from 1.3 to 1.6 , depending on meteorological inputs.

The AERMOD model operates in $1 \mathrm{~h}$ time steps and assumes steady-state conditions, continuous emissions, and conservation of mass, and concentrations predicted at a receptor resulting from different sources are additive. Pollutant distribution is modeled as Gaussian in the stable boundary layer in both the horizontal and vertical directions and in the horizontal direction in the convective boundary layer; vertical pollutant distribution in the convective boundary layer is modeled as bi-Gaussian (Cimorelli et al., 2005). The interface used to run this model was the commercially available AERMOD View package by Lakes En- 
vironmental Software (Waterloo, Ontario, Canada).

AERMOD requires hourly averaged meteorological data such as wind speed, wind direction, temperature, and solar radiation. These data were supplied by measurements made just south of and predominantly downwind of the dairy. Wind direction and incoming solar radiation data recorded at $5.0 \mathrm{~m}$ agl by the Davis weather station were utilized, along with wind speed data collected by the cup anemometer mounted at $6.2 \mathrm{~m}$ on the nearby tower, the closest level corresponding to the wind direction measurements at $5.0 \mathrm{~m}$. Temperature data were taken from the $2.5 \mathrm{~m}$ agl level on the tower. Cloud cover was set at zero for the entire study period, as there were clear skies throughout the measurement campaign.

The meteorological preprocessor for AERMOD, AERMET, also requires that values for Bowen ratio $(\beta)$, noontime albedo $(\alpha)$, and surface roughness length $\left(z_{0}\right)$ be specified by the user. The average $z_{0}$ was calculated from vertical wind speed profiles measured downwind of the dairy using the following equation, which relates wind speeds $\left(u_{1}\right.$ and $u_{2}$ in $\left.\mathrm{m} \mathrm{s}^{-1}\right)$ at two heights $\left(z_{1}\right.$ and $z_{2}$ in $\left.\mathrm{m}\right)$ and was derived from the integrated logarithmic wind speed profile equation:

$$
\frac{u_{2}}{u_{1}}=\frac{\ln \left(\frac{z_{2}}{z_{0}}\right)}{\ln \left(\frac{z_{1}}{z_{0}}\right)}
$$

A least sum of squares of residuals methodology was used to determine the value of $z_{0}$ that best fit the measured wind speeds at the higher elevation of two paired wind speed time series over the study period. A $z_{0}$ value of $0.09 \mathrm{~m}$ was calculated as the arithmetic average of the values that best fit six pairings of hourly averaged wind speeds measured at 3.9, 6.2, 9.7, and $15.3 \mathrm{~m}$ agl, i.e., 3.9 and $6.2 \mathrm{~m}, 3.9$ and $9.7 \mathrm{~m}, 3.9$ and $15.3 \mathrm{~m}, 6.2$ and $9.7 \mathrm{~m}, 6.2$ and $15.3 \mathrm{~m}$, and 9.7 and $15.3 \mathrm{~m}$.

Unlike $z_{0}$, data were not collected that could be used to calculate the $\beta$ and $\alpha$ values. Instead, summer values were selected from tables with seasonal values provided by EPA (2008). The selected $\beta$ value was 4.0, the suggested summer value for bare rock/sand/clay in an arid region under average soil moisture conditions. Despite soil moisture measurements from pen and road surfaces revealing dry conditions at the sample locations, the deposition of urine to pen surfaces by cattle and the presence of the LMS were used as justification for selecting the suggested value for average soil moisture conditions. The suggested noon-time $\alpha$ value of 0.20 for bare rock/sand/clay in an arid region was used in this study.

Faulkner et al. (2008) found that maximum $C_{\text {sim }}$ as predicted by AERMOD from a ground-level area source was sensitive to, among other input parameters, $\alpha$ and $z_{0}$ but not sensitive to $\beta$. The lack of sensitivity to $\beta$ was theorized to be due to the dominance of mechanical mixing in the planetary boundary layer in their application. Based on these findings, the sensitivity of $C_{\text {sim }}$ and the resulting $Q_{\text {meas }}$ estimates in this inverse modeling application to variations in $\alpha$ and $\beta$ was investigated. The sensitivity to $z_{0}$ was not tested, as it was calculated from measured data. Summer $\alpha$ values selected were 0.18 , the suggested value for fallow fields and supported by Hansen (1993) for light-colored, dry soil, such as that in the fields surrounding the dairy, and 0.25 , the suggested value for shrublands in an arid region. Two summer values for $\beta$ were selected: 1.5 , suggested for both wet conditions in a bare rock/sand/clay surface in an arid region and for fallow fields under dry conditions, and 6.0 for dry conditions in a bare rock/sand/clay surface in an arid region (EPA, 2008).

Four consecutive passive sampler measurement periods, two morning and two afternoon, were selected for the comparison. Changes in $C_{\text {sim }}$ and $Q_{\text {meas }}$ were calculated as a percentage of $C_{\text {sim }}$ and $Q_{\text {meas }}$ calculated at the base case of $\alpha=0.20$ and $\beta=4.0$. Values of $C_{\operatorname{sim}}$ at all downwind sites varied between $-3 \%$ and $+5 \%$ from the base case, although most were within $\pm 1 \%$. Estimates of $Q_{\text {meas }}$ under the different values of $\alpha$ and $\beta$ varied most for the LMS (-6\% to $+4 \%$ ), while the changes in pen and combined EF estimates were about equal at $-2 \%$ to $+1 \%$. Values of $C_{\text {sim }}$ increased, resulting in decreased $Q_{\text {meas }}$ estimates, with increasing $\alpha$ at constant values of $\beta$. Holding $\alpha$ constant while increasing $\beta$ had the opposite effect, leading to lower $C_{\text {sim }}$ values and thus higher $Q_{\text {meas }}$ estimates. Therefore, for this dairy and sampling layout, neither the $C_{\text {sim }}$ nor the $Q_{\text {meas }}$ estimated through inverse modeling with AERMOD were sensitive to the selected ranges of $\alpha$ and $\beta$.

AERMOD requires the source type, size, location, and emission rate be specified, as well as sampler/receptor locations. The pens, settling basin, and holding pond were specified as ground-level area sources with areal extents equal to their respective dimensions and with an initial plume height of $0 \mathrm{~m}$. The vertices of the sources and the receptor locations were taken from multiple hand-held GPS measurements made during the study and available satellite imagery. Pens not occupied by cattle were not included in the model; for example, only the quarter of the northern-most group of pens that was occupied by steers was specified as an active source.

Note that the value of the $(C / Q)_{s i m}$ ratio in equation 3 is the same across all ranges of $Q_{\text {sim }}$ when using a model with a proportionally linear response in $C_{s i m}$ to changes in $Q_{s i m}$; this also applies to the ratio of each source/receptor pairing in equation 4. This means that the ratio describes the slope of a straight-line relationship without local maxima or minima and eliminates the dependency of the results on the input $Q_{\text {sim }}$ values. However, the method used to determine the initial $Q_{s i m}$ values for each source $i$ for this study is important to note, as it was integrated into the optimization procedure. An initial estimate of the pen EF $(f)$ of $1.5 \mathrm{mg}$ animal ${ }^{-1} \mathrm{~s}^{-1}$, the yearly average $\mathrm{NH}_{3} \mathrm{EF}$ reported for an open-lot dairy by Leytem et al. (2010), was combined with animal occupancy ( $m$, number of cattle) and area $\left(A, \mathrm{~m}^{2}\right)$ as shown in equation 6 to calculate $Q_{s i m, i}$ values $\left(\mathrm{g} \mathrm{s}^{-1} \mathrm{~m}^{-2}\right)$ for the pens:

$$
Q_{\text {sim }, i}=\frac{f m_{i}}{A_{i}}
$$


The emission rates of the solids settling basin and the holding pond were assumed to be equal and given an initial value of $0.1 \mathrm{mg} \mathrm{m}^{-2} \mathrm{~s}^{-1}$, an average of the lower and upper ranges reported by Rumburg et al. (2008b). The initial estimates of $Q_{s i m}$ for each source were supplied to AERMOD, which was then run for each sample period. Calculated hourly $C_{\text {sim }}$ values were averaged over a sample period, e.g., from 12:00 noon until 12:00 midnight to correspond with a p.m. passive sample period, for comparison with $C_{\text {meas }}$.

The presence of the trailer on the downwind side of the dairy may have affected measurements at that location due to flow disruption. However, the potential effects on dispersion and nearby concentrations could not be modeled within AERMOD because the software does not allow the modeling of building effects with area sources. In addition, $\mathrm{NH}_{3}$ is known to deposit readily to most surfaces. Deposition likely occurred during this study, to some degree, in the short distance between the sources and measurement locations and resulted in lower $C_{\text {meas }}$ than if some $\mathrm{NH}_{3}$ had not deposited. However, deposition was neither measured nor simulated in this study. As a lower $C_{\text {meas }}$ results in a lower $Q_{\text {meas }}$, any depositional loss occurring between the source and the measurement location that is not accounted for in emissions calculations would lead to estimated EFs and ERs being lower than the actual values. In such cases, the calculated EFs and ERs should be considered as effective ERs and EFs.

A total of ten active sources were specified in the model. A sufficient number of downwind passive sampler measurements existed to calculate an emission rate for each individual source, but a maximum of six downwind OP-FTIR measurement paths yielded an under-determined system. Simplification of the system was performed and reduced the total number of emission rates solved for in the system to two based on the following: (1) as the solids settling basin and the holding pond $Q_{\text {sim }}$ were assumed to be equal, the change in $C_{\text {sim }}$ at a given location resulting from the entire LMS was assumed to be linear compared to the change in the sum of the LMS emissions per area per unit time $\left(Q_{\text {sim,LMS }}\right)$; and (2) as $m$ and $A$ in equation 6 are constants for a given pen source $i$, leaving only changes in $f$ to change $Q_{\text {sim, },}$, and the same value of $f$ was applied to each pen, a linear change in $C_{\text {sim }}$ resulting from all the pens at a given location to a change in the sum of the pen $Q_{\text {sim }, i}$ per unit area per unit time was assumed. Both assumptions were verified to be true through modeling with different $f$ and $Q_{\text {sim,LMS }}$ values.

Therefore, the system of linear algebra equations used to estimate the dairy $\mathrm{NH}_{3}$ ERs was designed to solve for $f_{\text {meas }}$ and $Q_{\text {meas,LMS }}$, yielding an over-determined system for both passive and OP-FTIR sampling configurations. The optimization method employed to solve these systems was a least sum of squares of residuals comparing $C_{\text {sim }}$ and $C_{\text {meas }}$. Reported EFs on a per animal basis were calculated for the LMS by relating the estimated ERs to the number of contributing animals, which was assumed to be limited to those in the milk cow pens due to the lack of feed lane flushing in other pens. The EF per animal for those in the milk cow pens was calculated as the sum of the pen EF and the LMS
EF. The average $\mathrm{NH}_{3} \mathrm{EF}$ across the facility was calculated as a weighted average of the pen EF and the summed EF for cattle in the milk cow pens, with weights assigned based on the number of cattle in the two categories. In addition, the overall study average EFs were calculated as weighted averages according to the number of EF estimates during each sample period throughout a day. For example, the reported OP-FTIR based averages represent the sum of the estimated emissions over a $24 \mathrm{~h}$ period using the average EFs for each $2 \mathrm{~h}$ block.

\section{RESULTS AND DISCUSSION}

The measurement campaign began at 12:00 noon Pacific Standard Time (PST) on 13 June 2008 and ended at 00:00 h PST on 21 June 2008. A total of 13 sample periods, approximately $12 \mathrm{~h}$ each, were conducted using the passive samplers, with all previous samples being collected and the next samples being deployed within $30 \mathrm{~min}$ of $00: 00 \mathrm{~h}$ and 12:00 noon PST. The upwind OP-FTIR unit operated nearly continuously from 14 June 04:20 h to 19 June 08:30 h. Data were collected by the downwind OP-FTIR unit from 13 June $13: 30 \mathrm{~h}$ to 21 June 00:00 h, operating for $118.9 \mathrm{~h}$ out of 178.5 total hours $(66.6 \%)$.

Meteorological conditions throughout the field study were hot and dry, with diurnally consistent wind patterns. Low wind speeds with highly variable direction were recorded each morning shortly before sunrise. The wind speed at $6.2 \mathrm{~m}$ agl from $05: 00$ to $06: 00 \mathrm{~h}$ varied between 0.6 and $1.5 \mathrm{~m} \mathrm{~s}^{-1}$ with a campaign average $\pm 1 \mathrm{SD}$ of $1.1 \pm 0.2 \mathrm{~m} \mathrm{~s}^{-1}$. The SD is reported in this article for all measurements unless otherwise noted to show the variability in the reported values. During the remainder of the day, winds came from the northwest. Figure 2 shows the dominance of winds from the northwest sector throughout the study, accounting for $74 \%$ of recorded values. Cloud cover was either absent or extremely light and at high altitudes throughout, with no recorded precipitation events. Samples of the soil on unpaved roads and in dry-lot pens were collected on 16 June and analyzed for percent moisture, resulting in averages of $0.56 \% \pm 0.50 \%(n=3)$ and $5.3 \% \pm 5.1 \%(n=7)$ for the unpaved roads and pens, respectively.

Campaign average meteorological conditions measured on-site are presented in table 3, as well as average conditions measured at the Stratford CIMIS site during the study period, for all of June 2008 and for the month of June from 1998 to 2007. Average conditions on-site were indistinguishable from those measured at Stratford for temperature, wind direction, and precipitation; wind speeds were slightly lower and relative humidity values were higher at the dairy, with little difference between upwind (data not shown) and downwind measurements. Comparison of the study period conditions at Stratford with the remainder of the month and during previous years reveals that this period was slightly warmer and drier than monthly averages, but with similar wind conditions. June 2008 was similar to past years in temperature and wind direction, with slightly higher average wind speeds and lower relative humidity values. It should be noted that the total precipitation in each column 
Table 3. Comparison of average meteorological conditions ( \pm 1 SD) measured at the dairy from 13-20 June 2008 and at a site in Kings County for the same period, for the full month of June 2008, and for the month of June from 1998 to 2007.

\begin{tabular}{ccccc}
\hline $\begin{array}{c}\text { Meteorological } \\
\text { Variable }\end{array}$ & $\begin{array}{c}\text { On-site, } \\
\text { 13-20 June } \\
2008\end{array}$ & $\begin{array}{c}\text { Off-site, } \\
13-20 \text { June } \\
2008\end{array}$ & $\begin{array}{c}\text { Off-site, } \\
\text { June } \\
2008\end{array}$ & $\begin{array}{c}\text { Off-site, } \\
\text { June } \\
1998-2007\end{array}$ \\
\hline $\begin{array}{c}\text { Temperature } \\
\left({ }^{\circ} \mathrm{C}\right)\end{array}$ & $26.5 \pm 6.7$ & $26.7 \pm 7.4$ & $24.8 \pm 7.2$ & $24.2 \pm 6.7$ \\
\hline $\begin{array}{c}\text { Relative humidity } \\
(\%)\end{array}$ & $41 \pm 18$ & $30 \pm 16$ & $33 \pm 17$ & $45 \pm 18$ \\
\hline $\begin{array}{c}\text { Wind speed } \\
\left(\mathrm{m} \mathrm{s}^{-1}\right)\end{array}$ & $2.4 \pm 1.1$ & $2.9 \pm 1.2$ & $3.2 \pm 1.7$ & $2.8 \pm 1.3$ \\
\hline $\begin{array}{c}\text { Wind direction } \\
\left({ }^{\circ}\right)\end{array}$ & $325 \pm 42$ & $326 \pm 42$ & $329 \pm 42$ & $330 \pm 45$ \\
\hline $\begin{array}{c}\text { Total precipitation } \\
(\mathrm{mm})\end{array}$ & 0.0 & 0.0 & 0.3 & 16.2 \\
\hline
\end{tabular}

is a summation of all data considered and that the sum of $16.2 \mathrm{~mm}$ comes from three recorded events from 1998 to 2007 during the month of June and is strongly driven by a single event totaling $14.0 \mathrm{~mm}$.

\section{Concentration Measurements}

A total of 298 samples were successfully collected upwind, downwind, and within the dairy using the passive samplers deployed at 23 locations. The average upwind concentration was $84.5 \pm 19.2 \mathrm{ppbv}\left(57.4 \pm 13.4 \mu \mathrm{g} \mathrm{m}^{-3}, n=\right.$ 86) with a range of 52.9 to 128.3 ppbv. Concentrations measured downwind varied much more, with a range of 69.3 to $1879.2 \mathrm{ppbv}$ and an average of $412.4 \pm 281.1 \mathrm{ppbv}$ $\left(280.0 \pm 188.6 \mu \mathrm{g} \mathrm{m}^{-3}, n=209\right)$. No passive samples exceeded the $12.1 \mu \mathrm{g} \mathrm{NH}$ collection threshold, after which the collection efficiency becomes non-linear. There was a significant difference in $\mathrm{NH}_{3}$ concentrations measured between morning (sampled from roughly 00:00 $\mathrm{h}$ to 12:00 noon) and afternoon (sampled from roughly 12:00 noon to 00:00 h) periods. Average morning levels were 99.3 $\pm 16.5 \mathrm{ppbv}(n=25)$ at upwind sites and $308.5 \pm 181.0 \mathrm{ppbv}$ $(n=89)$ at downwind sites. Afternoon concentrations averaged $78.7 \pm 16.9 \mathrm{ppbv}(n=60)$ and $489.4 \pm 315.3 \mathrm{ppbv}(n=$ 120) at upwind and downwind locations, respectively. The highest concentrations in each period were measured between the holding pond and the young heifer pens and downwind of the milk cow pens. These concentrations were in the range of values reported by Cassel et al. (2005), Bjorneberg et al. (2009), and Leytem et al. (2009) at openlot dairies in California and Idaho.

Ammonia concentrations recorded by the OP-FTIR units were more frequent than the passive sampler measurements, thus providing more information about the diurnal pattern and temporal variation in concentrations. However, these values are volumetrically averaged concentrations across the beam area (diameter $\approx 0.3 \mathrm{~m}$ ) and along the length of the beam path (140 to $290 \mathrm{~m}$, depending on pointing position). Thus, the OP-FTIR units provide less spatial information than the passive samplers. Figure 3 presents a five-day time series of data collected at 2 to $2.5 \mathrm{~m}$ agl along five different beam paths (see fig. 1 for beam path locations). Reported levels of $\mathrm{NH}_{3}$ are in the same range as those calculated from passive sampler measurements, as well as measurements given in the literature from dairies with similar housing and manure management systems (Cassel et al., 2005; Bjorneberg et al., 2009; Leytem et al., 2009). Note that the highest $\mathrm{NH}_{3}$ concentrations throughout the period were detected to the east of the centrally located downwind OP-FTIR unit, which is immediately downwind of both the LMS area and milk cow pens. Additionally, the highest concentrations detected downwind of the dairy were recorded in the evening and early morning hours while the lowest $\mathrm{NH}_{3}$ levels were measured in late morning and at mid-day. Sharp increases and decreases in $\mathrm{NH}_{3}$ levels at the upwind beam path correspond with the 05:00 to 06:00 $\mathrm{h}$ periods of light winds of variable direction discussed previously.

The concentrations reported at upwind sites from both measurement methodologies are high for ambient levels not immediately adjacent to a source, which is indicative of the size and density of $\mathrm{NH}_{3}$ sources in the region. Kings County, the county in which this dairy is located, and Fresno County, the county north and northwest of Kings County,

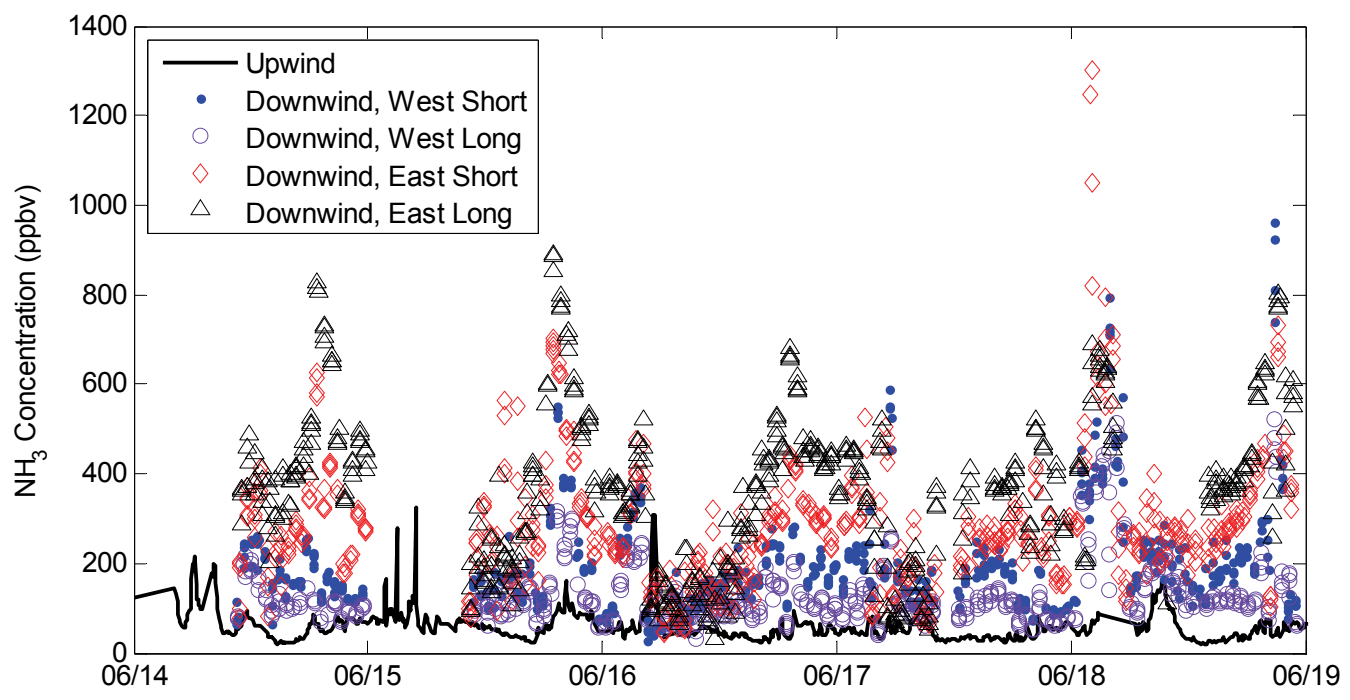

Figure 3. $\mathrm{NH}_{3}$ concentration (ppbv) measured by both the upwind and downwind OP-FTIR instruments at approximately 2 m agl. Downwind beam paths are described by the direction from the monostatic unit to the retroreflector and the relative distance to the retroreflector. 
had a combined 2007 animal population (with animal density given in parentheses) of 789,612 cattle $\left(41.1 \mathrm{~km}^{-2}\right)$ including 278,368 milk cows $\left(14.5 \mathrm{~km}^{-2}\right)$ and 26,999 beef cows $\left(1.4 \mathrm{~km}^{-2}\right), 9,809$ hogs $\left(0.5 \mathrm{~km}^{-2}\right)$, and $89,860,417$ broiler chickens, all in Fresno County $\left(4,682.9 \mathrm{~km}^{-2}\right)$ (USDA, 2009). Battye et al. (2003) provided a summary of three $\mathrm{NH}_{3}$ emissions inventories for the Fresno County area, all of which estimated livestock's contribution at $50 \%$ to $75 \%$ of the total emissions, which ranged from 71,000 to 99,000 Mg year ${ }^{-1}$. Winter background $\mathrm{NH}_{3}$ measurements in the San Joaquin Valley of California ranged from 16 to $96 \mathrm{mg} \mathrm{m}^{-3}$ (Cassel et al., 2005). Robarge et al. (2002) reported a summer average $\mathrm{NH}_{3}$ concentration of $10.5 \mu \mathrm{g} \mathrm{m}^{-3}$ from measurements taken in the agriculture-rich Inner Coastal Plain of North Carolina. Walker et al. (2004) summarized literature values collected in agricultural, nonagricultural, and urban land use settings from 11 studies, with average concentrations ranging from $0.02 \mu \mathrm{g} \mathrm{m}^{-3}$ at high elevation during summer to $10.48 \mu \mathrm{g} \mathrm{m}^{-3}$ during fall at a swine facility. Moore (2007) reported winter and summer average concentrations of 28.8 and $24.7 \mu \mathrm{g} \mathrm{m}^{-3}$, respectively, throughout the Cache Valley, a heavily agricultural valley along the Utah/Idaho border with significant dairy cattle and layer hen populations. Leytem et al. (2009) reported background $\mathrm{NH}_{3}$ levels ranging from 10 to $60 \mu \mathrm{g} \mathrm{m}^{-3}$ in another area of Idaho with a high dairy density.

On a path-by-path comparison, passive sampler $\mathrm{NH}_{3}$ levels were higher than OP-FTIR measurements by an average of $1.38 \pm 0.15(n=50)$. One possible explanation for the difference between the reported concentrations in the passive and OP-FTIR datasets is the difference in methodology. Another possible cause is the effectiveness of a limited number of discrete sampling points to represent a concentration field in close proximity to strong sources, which is somewhat related to the first possible explanation. To conduct these comparisons, the two to four passive samplers located along each OP-FTIR beam path were used to calculate the path length average passive sampler concentration, and OP-FTIR measurements were averaged over the passive sampler deployment time to calculate the period average OP-FTIR concentration. The sample heights of the passive samplers were set as close to the height of the OPFTIR beam path as possible, although some were up to $1 \mathrm{~m}$ lower. The crosswind scale of the source in relation to the distance between sampling points, as well as the distance from the source to the sampling points, could have significant impacts on how representative the measured concentration field derived from a few sample points is compared to the actual concentration field. While the spatial scales of most of the sources on the dairy are large compared to the distances between samplers, the homogeneity of the emissions from the pen and LMS surfaces may vary significantly on scales smaller than the distance between sampling points and create emissions hotspots. The result is a nonuniform concentration profile across the plume that may or may not be effectively sampled by the point samplers. The path-integrated sample of the OP-FTIR has the advantage in that it can sample the entire width of the plume, but spatial information available from an adequate number of point sensors is sacrificed.

Going et al. (2008) found that passive sampler measurements were on average $55 \%$ greater than OP-FTIR measurements when the passive samplers were deployed as directed by the manufacturer. Meng et al. (2011) compared seven-day $\mathrm{NH}_{3}$ concentration averages reported by Ogawa passive samplers and an active $\mathrm{NO}_{x} / \mathrm{NH}_{3}$ analyzer and found a strong correlation, yielding a linear fit slope of 1.21 with the active analyzer as the independent variable and the passive sampler as the dependent variable. Puchalski et al. (2011) compared two and three week long average $\mathrm{NH}_{3}$ concentrations from Ogawa passive samplers against other passive samplers and an active analyzer over a 0.5 to $9.0 \mu \mathrm{g}$ $\mathrm{m}^{-3}$ range and found that the Ogawa sampler reported values not statistically different from the other passive samplers in one study and $36 \%$ lower than the active sampler in another study.

\section{ESTIMATED EMISSIONS}

The ERs and EFs for this study were estimated through inverse modeling. Screening of the datasets to identify periods in which the wind direction was outside of the optimal range of $-70^{\circ}$ to $+50^{\circ}$ from north yielded a total of $12 \mathrm{~h}$ $(8 \%)$ during five of the 13 passive sampler deployment periods. One period, June 14 a.m., had six hourly average wind direction values outside the optimal range; the remaining four periods had 1 to $2 \mathrm{~h}$ each. The June 14 a.m. period was removed from ER and EF calculations, while the other four passive sampler periods were not removed due to the limited amount of time in each period that the sites were not impacted by the dairy and the ability of the model to simulate the effects of these non-ideal wind directions on period average concentrations.

The $C_{\text {meas }}$ values calculated for the two locations between the young heifer pens and the holding pond, the locations with the largest reported concentration values during all sample periods, were excluded from emissions estimation calculations because of doubt that they were only influenced by the pens. It is hypothesized that the feed lane fencing on the south side of the pen immediately upwind likely presented a flow disturbance sufficient to allow some of the holding pond plume to be circulated in the upwind direction. The samplers were located within a few meters of the northern edge of the holding pond and had a sample height of $1 \mathrm{~m}$. Removal of these two points resulted in EF estimates with better fits to the remaining $C_{\text {meas }}$ data.

There were 78 potential OP-FTIR sample periods during the field study based on $2 \mathrm{~h}$ averages. Irregularities with instrument operation, alignment, and retroreflector cleanliness reduced the number of periods with valid data from two or more downwind beam paths to 48 , or $62 \%$. Of these, six were removed due to wind directions outside of the optimal range, yielding a total of 42 sample periods from which to calculate ERs and EFs. These irregularities and non-optimal wind directions disproportionately affected the morning blocks (00:00 h through 12:00 noon), which had only two or three valid datasets in most $2 \mathrm{~h}$ blocks for ER and EF calculations, about half as many as in the afternoon. This likely contributed to the greater RSDs in the average emissions from the pens and the entire facility for morning 
blocks when compared to the afternoon blocks. As previously mentioned, light and variable winds were observed each day during 05:00-06:00 $\mathrm{h}$, resulting in no valid data points for the block ending at 06:00 $\mathrm{h}$. To provide an emissions estimate for this period, a gap-filling technique was used based on the average of the 04:00 $\mathrm{h}$ and 08:00 $\mathrm{h}$ blocks.

The unconstrained least squares optimization method initially used in estimating ERs and EFs generally performed well, but it yielded negative emissions from either the pens or the LMS in a few instances. This phenomenon was neither observed in measured data nor is it considered to be real. It is instead assumed to be an artifact of the optimization method. Flesch et al. (2009b) suggested setting a minimum ER value in such cases. This recommendation was applied to our emissions calculations using a minimum pen $f_{\text {meas }}$ value of $0.5 \mathrm{~g} \mathrm{~d}^{-1}$ animal ${ }^{-1}$ and a minimum $Q_{\text {meas.LMS }}$ value of $0.5 \mathrm{mg} \mathrm{m}^{-2} \mathrm{~d}^{-1}$, which were estimated from minimum values given by Leytem et al. (2010) for an $\mathrm{NH}_{3}$ and greenhouse gas emissions study conducted at an open-lot dairy.

Flesch et al. (2009b) also suggested designing sampling layouts for multiple sources in such a way that each measurement location is impacted by only one source. If that ideal situation is not possible, as in the case of this dairy, and assuming at least the same number of measurements as sources, they suggest that the measurement sites be located such that the first site is impacted by only one source, the second site is impacted by the first source plus the second source, the third site by the first, second, and third sources, and so on. Emissions can then be estimated in a progressive manner. This sequential ER estimation methodology was applied to the passive sampler dataset. Some sites were impacted only by pens, while others were impacted by both pens and the LMS, allowing first the pen $f_{\text {meas }}$ and then the $Q_{\text {meas,LMS }}$ to be calculated. Determination of the sources impacting a given sample was made based on the range of hourly average wind directions measured during the sample period. The number of sites used to estimate the pen $f_{\text {meas }}$ ranged from 3 to 7, while 6 to 13 sites were used to estimate $Q_{\text {meas, LMS }}$. This sequential method was not applied to the OP-FTIR dataset because the downwind OP-FTIR unit in the center of the configuration was rarely not downwind of the LMS, resulting in all beam paths being impacted by both the pens and the LMS most of the time.
Another important point discussed by Flesch et al. (2009b) concerns the matrix conditioning number ( $\kappa)$, which is a measure of the sensitivity of the estimated $Q_{\text {meas }}$ vector in equation 4 to changes in the $(C / Q)_{s i m}$ ratios. If a change in $Q_{\text {meas }}$ is proportional to the change in a $(C / Q)_{\text {sim }}$ value, the system is referred to as well-conditioned and has a low $\kappa$ value (minimum $\kappa=1.0$ ). A system is said to be illconditioned if a large change in $Q_{\text {meas }}$ is found from a small change in $(C / Q)_{\text {sim }}$, which would result in a large $\kappa$ value. The value of $\kappa$ also is related to the relative error in estimates of $Q_{\text {meas }}$. Refer to Flesch et al. (2009b) for an indepth discussion with examples. An important conclusion was that accurate emissions estimates in controlled-release experiments with various source/receptor configurations were strongly dependent on $\kappa$. Good ensemble averaged estimates of the total amount released were calculated for $(C / Q)_{\text {sim }}$ matrices with $\kappa$ values less than 50 , and good estimates of the individual source contributions were found for matrices with $\kappa$ values less than 10 to 20 . Values of $\kappa$ calculated for the matrices in this dairy emissions study based on passive sampler data ranged from 1.5 to 2.7 , suggesting good confidence in the emissions estimates. Values of $\kappa$ calculated for matrices based on OP-FTIR data ranged from 4.5 to 25.6 , again suggesting good confidence in the emissions estimates.

The averages, SDs, minimums, and maximums of the EFs calculated using the three optimization methods discussed above for both datasets are presented in table 4. Average EF values estimated from the passive dataset for the unconstrained and constrained values were very similar, but greater differences were found between methodologies in the EF values based on OP-FTIR data. All reported statistics for the pen and whole facility EFs predicted by the progressive methodology based on passive sampler data were lower than for the other two methods; average estimated LMS EFs were higher for the progressive method and had a greater range in individual values. Average EFs based on OP-FTIR data for the pens, LMS, and the whole facility were higher than those based on passive sampler data and had a wider range between minimum and maximum values. One factor likely contributing to the larger range between maximum and minimum values based on OP-FTIR data is the greater temporal resolution in the OPFTIR dataset, $2 \mathrm{~h}$ averages versus $12 \mathrm{~h}$ averages for passive

Table 4. Statistics of emission factors (EFs) calculated for both $\mathrm{NH}_{3}$ measurement datasets using the following three optimization procedures: unconstrained $=$ EF values for pen and liquid manure system (LMS) are unconstrained; constrained = constraints are imposed on the minimum values for pen and LMS EFs based on minimum values found in the literature; and sequential = pen EF is estimated first from samples impacted only by pens and then LMS EF is estimated from samples impacted by both pens and LMS. ${ }^{\text {[a] }}$

\begin{tabular}{|c|c|c|c|c|c|c|c|c|c|c|c|c|}
\hline \multirow{2}{*}{$\begin{array}{l}\text { Optimization } \\
\text { Procedure }\end{array}$} & \multicolumn{4}{|c|}{$\begin{array}{c}\text { Pen EF } \\
\left(\mathrm{g} \mathrm{d}^{-1} \text { animal }^{-1}\right)\end{array}$} & \multicolumn{4}{|c|}{$\begin{array}{c}\text { LMS EF } \\
\left(\mathrm{g} \mathrm{d}^{-1} \text { animal }^{-1}\right)\end{array}$} & \multicolumn{4}{|c|}{$\begin{array}{c}\text { Facility EF } \\
\left(\mathrm{g} \mathrm{d}^{-1} \text { animal }^{-1}\right)\end{array}$} \\
\hline & Avg. & $\mathrm{SD}$ & Min. & Max. & Avg. & $\mathrm{SD}$ & Min. & Max. & Avg. & SD & Min. & Max. \\
\hline \multicolumn{13}{|l|}{ Passive sampler data } \\
\hline Unconstrained & 134.2 & 41.4 & 32.5 & 313.0 & 12.7 & 9.9 & -3.6 & 63.1 & 140.7 & 42.5 & 33.4 & 324.2 \\
\hline Constrained $^{[\mathrm{b}]}$ & 133.3 & 41.5 & 30.1 & 313.0 & 13.6 & 9.9 & 0.0 & 63.1 & 140.2 & 42.6 & 30.1 & 324.2 \\
\hline Sequential & 106.4 & 25.5 & 8.4 & 230.8 & 18.8 & 14.5 & -12.1 & 85.7 & 116.1 & 26.6 & 13.2 & 251.2 \\
\hline \multicolumn{13}{|l|}{ OP-FTIR data } \\
\hline Unconstrained & 158.7 & 37.6 & -213.7 & 661.4 & 53.3 & 23.1 & -40.2 & 521.2 & 186.0 & 28.7 & -109.4 & 661.6 \\
\hline Constrained $^{[\mathrm{b}]}$ & 177.8 & 27.3 & 0.5 & 661.5 & 41.6 & 17.7 & 0.0 & 455.7 & 199.2 & 21.9 & 8.4 & 661.6 \\
\hline Sequential & NA & NA & NA & NA & NA & NA & NA & NA & NA & NA & NA & NA \\
\hline
\end{tabular}

[a] $\mathrm{EF}=$ emission factor, Avg. = average, $\mathrm{SD}=$ standard deviation, Min. = minimum, Max. = maximum, and $\mathrm{NA}=$ not applicable.

[b] Optimization methodology selected as yielding the best EF estimates from this facility. 
samplers, allowing it to show greater diurnal variation in estimated EFs with smaller minimum values and larger maximum values that are smoothed out in the passive sampler EFs.

As previously stated, negative EFs were calculated from both the passive sampler and OP-FTIR data using the unconstrained methodology. Negative EFs values are not considered to be real and are assumed to be an artifact of the optimization method. Therefore, the EFs estimated through the constrained methodology were considered to be better estimates despite having imposed minimum values, a conclusion supported by the findings of Flesch et al. (2009b). Surprisingly, negative LMS EF values were also given by the progressive methodology based on the passive sampler data. These results may suggest shortcomings in this inverse modeling procedure, including the following: (1) the assumption of homogenous source strength across a pen or liquid surface is not valid for this case, (2) the assumption of equal emissions per animal is not valid for this case, (3) the combined dairy and sample layout employed in this study are not conducive to estimating $\mathrm{NH}_{3}$ emissions from individual components, or (4) another factor not accounted for in this analysis influenced $\mathrm{NH}_{3}$ emissions. The first assumption is required without prior knowledge of the magnitude and spatial patterns of the inhomogeneity. The second assumption is also required, as this study seeks to determine emissions from the entire facility and it is impractical to examine emissions from individual cattle. The third shortcoming may have merit, although the low calculated $\kappa$ values suggest that the systems of linear algebraic equations are, for the most part, very well-conditioned and should yield good estimates of the total and individual source emissions. It is likely that not all factors affecting $\mathrm{NH}_{3}$ emissions are accounted for in this analysis, as there are many factors that contribute (e.g., Arogo et al., 2006; Rumburg et al., 2008a, 2008b). Future $\mathrm{NH}_{3}$ emissions experiments should be designed to account for as many factors as feasibly possible.

The negative results for individual components may cast doubt on the ability of the present modeled scenario to quantify the emissions from individual sources. However, as shown by Flesch et al. (2009b), application of a minimum EF limit can significantly improve the ER estimation of individual components. In addition, the ER of the facility as a whole can be estimated well even when negative ERs are calculated for individual components. Therefore, the optimization methodology selected to best represent the actual EFs from the individual components and from the dairy as a whole was the constrained methodology. This resulted in an estimated summer total facility $\mathrm{NH}_{3}$ emission of $265.2 \pm 80.2 \mathrm{~kg} \mathrm{~d}^{-1}$ and an average EF of $140.7 \pm 42.5 \mathrm{~g} \mathrm{~d}^{-1}$ animal ${ }^{-1}$ based on the passive sampler dataset. Calculated values based on the OP-FTIR dataset were $40 \%$ higher, with a total facility emission of 375.4 $\pm 27.1 \mathrm{~kg} \mathrm{~d}^{-1}$ and an EF of $199.2 \pm 21.9 \mathrm{~g} \mathrm{~d}^{-1}$ animal $^{-1}$. These EF values are listed in table 5, along with EF values reported in other dairy $\mathrm{NH}_{3}$ emissions studies. The type of facility, geographical location, methodology used to estimate EFs, and season of the year and ambient tem- peratures in which measurements were made are also provided to allow for comparison between the different housing, climate, and manure storage and treatment conditions that may affect $\mathrm{NH}_{3}$ EFs. Seasonal EFs, specifically summer EFs, are provided where available for comparison against the values derived from the limited summer dataset described herein.

The summer facility EFs calculated for this dairy based on data collected over seven days are near the top of the range of EFs found in the literature, which spans two orders of magnitude, but within the range of values reported for facilities with open-lot pens and holding pond configurations (Mukhtar et al., 2008; Bjorneberg et al., 2009; Leytem et al., 2010). Specifically, the summer EFs derived herein are close to the summer EFs reported by Bjorneberg et al. (2009) and Leytem et al. (2010) for open-lot dairies but generally higher than the summer EFs reported for other housing and manure management configurations. Not all studies found in the literature estimated emissions from the entire dairy facility (housing, exercise area, manure storage and treatment system), as was measured in this study, which is necessary in order to estimate emissions for an entire facility. If this dairy's summer emissions were calculated based on literature from the U.S. that reported EFs for an entire facility without regard for housing, climate, and manure management system, they would range from $59.9 \mathrm{~kg} \mathrm{~d}^{-1}$ (from Mukhtar et al., 2008) to $625.8 \mathrm{~kg} \mathrm{~d}^{-1}$ (from Leytem et al., 2013). Note that Mukhtar et al. (2008) utilized a flux chamber, a methodology that yields results for the environment within the chamber and may not represent actual ambient conditions, as well as being susceptible to insufficient sampling of the high variability in urine and manure deposition, soil moisture, soil temperature, and other influential surface conditions that are typically found in an open-lot dairy configuration.

Pen emissions estimated during this study accounted for $95 \%$ of the total emissions based on passive sampler data and $89 \%$ of the total based on OP-FTIR data. This result is supported by both $C_{\text {meas }}$ datasets. Ammonia levels were consistently highest immediately downwind of the milk cow pen areas on the eastern side of the measurement layout, and $C_{\text {meas }}$ from sites downwind of the LMS were also impacted by the pen areas. As the optimization methods were designed to yield the best fit of $C_{\text {sim }}$ to $C_{\text {meas }}$, this led to pen emissions accounting for a large portion of the facility's emissions. ( $C_{\text {meas }}$ values from between the young heifer pens and the holding pond were excluded from ER/EF calculations, as previously described; however, if they were included, the pens had a higher contribution to total emissions.) As stated previously, $\mathrm{NH}_{3}$ emissions originate from $\mathrm{N}$ excreted in the manure and urine (Arogo et al., 2006). The dominance of the pens in total $\mathrm{NH}_{3}$ emissions may be explained by reviewing where manure and urine are deposited and stored in this open-lot system. Feces from about half of the cattle on the facility, basically all but the milk cows, remain in the pen for up to one year and do not enter the LMS. Only the feed lanes in the milk cow pens and the milking parlor floors are flushed, which is a very small percentage of the potential feces deposition area in the milk 
Table 5. Comparison of dairy $\mathrm{NH}_{3}$ emission factors (EFs) estimated from this study with EFs reported in the literature. When necessary, conversions between reported emissions units and those used in this table were made.

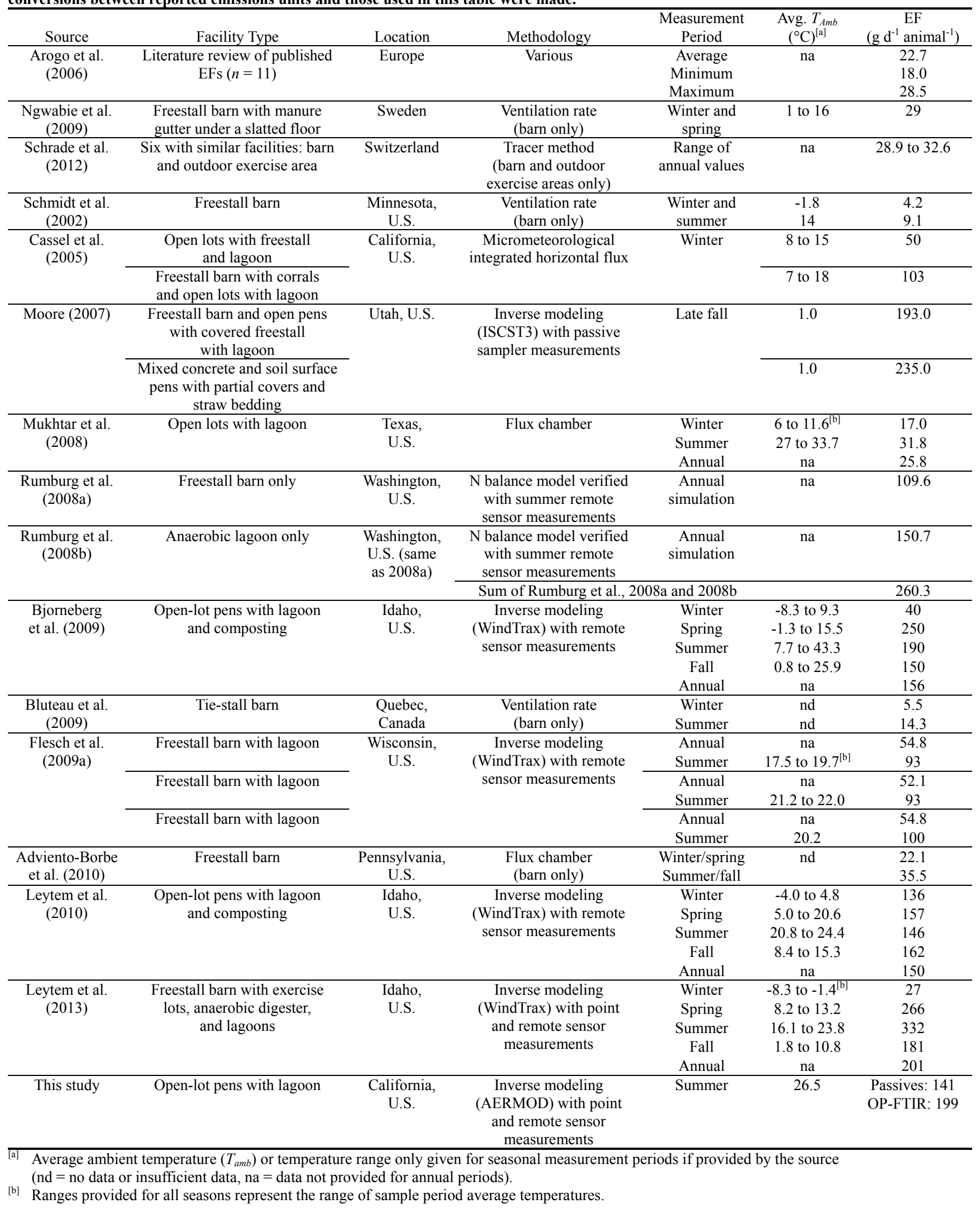

cow pen area. In addition, the feed lanes are not shaded, which may affect cattle behavior by decreasing time spent in the feed lane eating and increasing time spent in the shade on the open-lot area of the pen, especially during the summer. Direct solar radiation on the feed lane increases available energy at the surface and likely increases emissions from deposited feces. Furthermore, intermittent flushing throughout the day allows for the accumulation of feces 
in the feed lane and may provide sufficient time for a significant portion of the $\mathrm{N}$ in the urine to volatilize as $\mathrm{NH}_{3}$ before being flushed into the LMS (Arogo et al., 2006).

Bjorneberg et al. (2009) and Leytem et al. (2010) also found that pen areas produced most of the $\mathrm{NH}_{3}$ emissions on dairies with open lots and holding ponds, with summer contributions of $88 \%$ and $70 \%$, respectively. However, Rumburg et al. (2008a, 2008b), Flesch et al. (2009a), and Leytem et al. (2013) found that summer emissions were generally dominated by the LMS for dairy systems using barns and holding ponds/treatment lagoons and, in the case of Leytem et al. (2013), an anaerobic digester. The difference in the manure management between the dairy systems would help explain the difference in dominant sources between these groups. Manure is usually stored in the openlot pens, with removal occurring once or twice yearly, while manure is generally removed daily from the barns and stored or treated elsewhere.

The LMS ERs estimated from this dairy averaged $1.7 \pm 1.3 \mathrm{~g} \mathrm{~d}^{-1} \mathrm{~m}^{-2}$ and $5.5 \pm 2.3 \mathrm{~g} \mathrm{~d}^{-1} \mathrm{~m}^{-2}$ based on the passive sampler and OP-FTIR datasets, respectively, as calculated from the daily total emissions. Both calculated ERs are within the range of values found for dairy lagoons in the literature. Mukhtar et al. (2008) measured a summer average ER of $0.45 \mathrm{~g} \mathrm{~d}^{-1} \mathrm{~m}^{-2}$ and a winter average of $0.03 \mathrm{~g}$ $\mathrm{d}^{-1} \mathrm{~m}^{-2}$. The range of $\mathrm{NH}_{3}$ ERs for an anaerobic dairy lagoon reported by Rumburg et al. (2008b) was from 2.6 to $13.0 \mathrm{~g} \mathrm{~d}^{-1} \mathrm{~m}^{-2}$. Flesch et al. (2009a) measured no emissions from lagoons that were frozen over during winter and reported a range of 2.3 to $8.7 \mathrm{~g} \mathrm{~d}^{-1} \mathrm{~m}^{-2}$ during summer and fall. Moore (2007) calculated ERs for two holding ponds in series during late fall to be 4.1 and $1.3 \mathrm{~g} \mathrm{~d}^{-1} \mathrm{~m}^{-2}$ for the first and second ponds, respectively. An average emission of $8.8 \mathrm{~g} \mathrm{~d}^{-1} \mathrm{~m}^{-2}$ was reported by Sheffield and Louks (2006). Zhao et al. (2007) measured an average ER of $6.2 \mathrm{~g} \mathrm{~d}^{-1} \mathrm{~m}^{-2}$, a minimum of $0.5 \mathrm{~g} \mathrm{~d}^{-1} \mathrm{~m}^{-2}$, and a maximum of $15.1 \mathrm{~g} \mathrm{~d}^{-1}$ $\mathrm{m}^{-2}$ from measurements collected one day per month over ten months.

Similar to $\mathrm{NH}_{3}$ concentrations measured downwind of the dairy, a diurnal profile was evident in the estimated emissions from both datasets. Figure 4 shows the estimated emissions diurnal profile for the pens, the LMS, and the entire facility based on the OP-FTIR data. Note that no $2 \mathrm{~h}$ block periods ending at 06:00 $\mathrm{h}$ were available, and the values shown in this figure for that time of day were calculated as the average of the mean emissions values from the periods ending at 04:00 $\mathrm{h}$ and 08:00 h. Average calculated facility $\mathrm{NH}_{3}$ emissions during early morning hours were 15 times lower than peak emissions in the late afternoon and early evening. LMS emissions peaked during mid-day and contributed a greater amount of the total hourly emissions during those hours relative to the rest of the day. Cassel et al. (2005), Flesch et al. (2009a), and Leytem et al. $(2010,2013)$ also reported diurnal $\mathrm{NH}_{3}$ emissions patterns, but with peaks occurring during early afternoon and with emissions remaining high through the late afternoon and early evening. Bjorneberg et al. (2009) reported peak pen emissions during the evening in the spring and during late afternoon in the summer.

Good temporal correlations were found between facility $\mathrm{NH}_{3}$ emissions and $2 \mathrm{~h}$ block averaged ambient temperature $(r=0.65)$ and wind speed $(r=0.63)$, based on the Pearson correlation coefficient $(r)$. The LMS emissions did not have significant correlations with temperature and wind speed, but they had a moderate correlation with incoming solar radiation $(r=0.45)$. As incoming solar radiation directly affects several surface and atmospheric properties, it is likely that this correlation exists because of solar radiation's effect on a property that more directly influences $\mathrm{NH}_{3}$ volatilization but was not monitored, e.g., liquid surface temperature. Assuming that the emissions calculated for individual source types are representative, these results suggest different diurnal emissions cycles between the pens and LMS during this study. The temporal emissions patterns and correlations found at this dairy may or may not hold under different seasonal patterns. Measurements at this dairy during other seasons are needed to investigate the applicability of these patterns and correlations throughout the year.

Air temperature and wind speed have been shown to be significant factors, among others, that affect $\mathrm{NH}_{3}$ volatiliza-

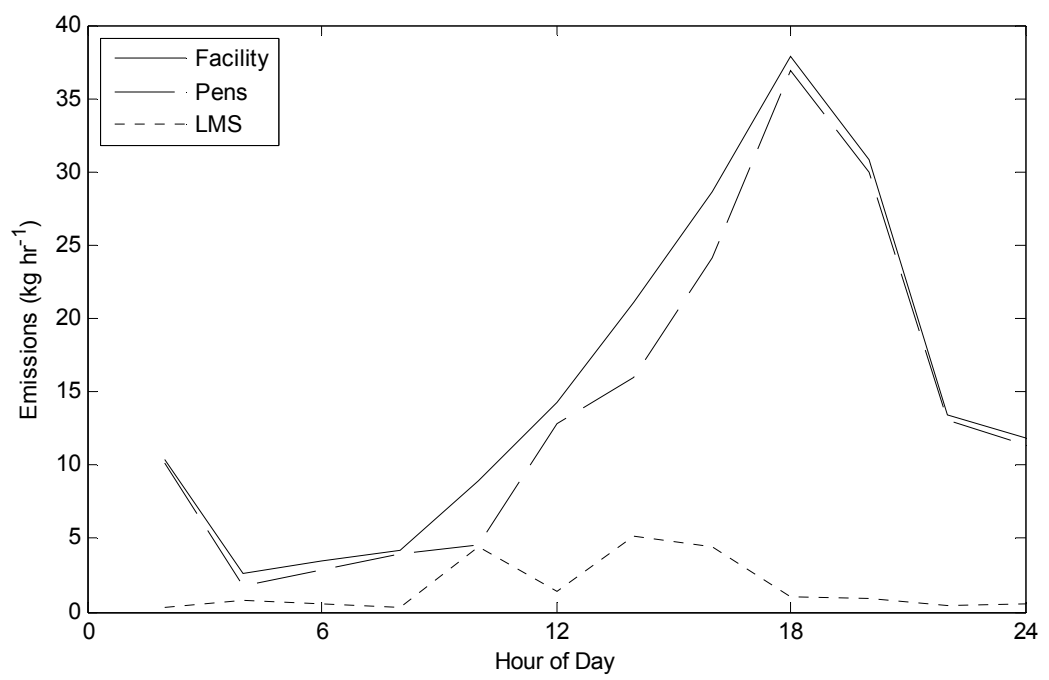

Figure 4. Estimated diurnal emissions profiles for the pens, LMS, and entire facility based on $2 \mathrm{~h}$ averaged OP-FTIR data. 
tion (Beauchamp et al., 1982; Sommer et al., 1991, 2003; Cassel et al., 2005; Arogo et al., 2006). Temperature is also a factor in estimating volatilization based on Henry's law. The demonstrated effect of temperature on $\mathrm{NH}_{3}$ emissions raises the question of the representativeness of the EFs and total emissions calculated during this short period in June as representative for the summer period. Daily and weekly temperature averages and ranges during the months of July and August may be higher than those measured during this study. However, the mean monthly average values reported by the CIMIS station near Stratford, California, for July and August from 1998 to 2007 for the average temperature, average daily maximum temperature, and average daily minimum temperature were each within $2^{\circ} \mathrm{C}$ of the corresponding statistical values calculated from on-site measurements made during this study. Therefore, the facility emissions and EFs herein presented are assumed to be representative of monthly average summer values.

\section{CONCLUSION}

Summer gaseous $\mathrm{NH}_{3}$ concentrations were measured upwind, downwind, and within an open-lot dairy over seven days using passive samplers and OP-FTIR units to estimate the facility's total emissions and EFs. These are the first reported summer $\mathrm{NH}_{3}$ emissions measurements for California, the state with the nation's largest dairy cattle population. Background $\mathrm{NH}_{3}$ concentrations measured during this study were high relative to ambient concentrations found in the literature, suggesting that the San Joaquin Valley is a very rich source area for $\mathrm{NH}_{3}$. This is supported by agricultural livestock statistics reported in the 2007 Census of Agriculture (USDA, 2009). Emissions from both the pens and the LMS were estimated from both concentration datasets using inverse modeling with AERMOD and least squares optimization methods. Average emissions $\pm 1 \mathrm{SD}$ for the entire facility were calculated as $140.7 \pm 42.5 \mathrm{~g} \mathrm{~d}^{-1}$ animal $^{-1}\left(113.5 \pm 34.3 \mathrm{~g} \mathrm{~d}^{-1} \mathrm{AU}^{-1}\right)$ from the passive sampler data and 199.2 $\pm 22.0 \mathrm{~g} \mathrm{~d}^{-1}$ animal ${ }^{-1}\left(160.8 \pm 17.8 \mathrm{~g} \mathrm{~d}^{-1} \mathrm{AU}^{-1}\right)$ from the OP-FTIR data. The facility's calculated summer emissions were $265.2 \pm 80.2 \mathrm{~kg} \mathrm{~d}^{-1}$ and $375.4 \pm 27.1 \mathrm{~kg} \mathrm{~d}^{-1}$ based on EFs calculated from the passive and OP-FTIR datasets, respectively. The pens were estimated to contribute $95 \%$ and $89 \%$ of the total facility emissions for the passive sampler and OP-FTIR based EFs, respectively. Derived EFs were within the range of EF values from U.S. dairies found in the literature, a range that spans two orders of magnitude. Mean LMS ERs were $1.7 \pm 1.3 \mathrm{~g} \mathrm{~d}^{-1} \mathrm{~m}^{-2}$ based on passive sampler data and $5.5 \pm 2.3 \mathrm{~g} \mathrm{~d}^{-1} \mathrm{~m}^{-2}$ based on OP-FTIR data, which are within the range of literature values from other dairy lagoons and holding ponds. A strong diurnal cycle was observed in both concentrations and emissions datasets, with the highest values occurring in the late afternoon and evening. Calculated daily maximum emissions were 15 times greater than daily minimum values based on OP-FTIR data. Good correlations between facility emissions and temperature and wind speed were found with the $2 \mathrm{~h}$ block averaged OP-FTIR emissions data, while LMS emissions had a moderate correlation with incoming solar radiation.

\section{ACKNOWLEDGEMENTS}

This material is based on work supported by the USDA (Cooperative Agreement No. 58-3625-9-743). The authors thank the producers for their cooperation, the team involved in conducting the field work, and the reviewers, whose feedback greatly enhanced the quality of the manuscript.

\section{REFERENCES}

Adviento-Borbe, M. A., Wheeler, E. F., Brown, N. E., Topper, P. A., Graves, R. E., Ishler, V. A., \& Varga, G. A. (2010). Ammonia and greenhouse gas flux from manure in freestall barn with dairy cows on precision fed rations. Trans. ASABE, 53(4), 1251-1266. http://dx.doi.org/ 10.13031/2013.32590.

Arogo, J., Westerman, P. W., Heber, A. J., Robarge, P. W., \& Cassen, J. J. (2006). Ammonia emissions from animal feeding operations. In Animal Agriculture and the Environmental: National Center for Manure and Animal Waste Management White Papers, 41-88. J. M. Rice, D. F. Caldwell, \& F. J. Humenik, eds. St. Joseph, Mich.: ASABE.

ASABE Standards. (2005). D384.1: Manure production and characteristics. St. Joseph, Mich.: ASABE.

Battye, W., Aneja, V. P., \& Roelle, P. A. (2003). Evaluation and improvement of ammonia emissions inventories. Atmos. Environ., 37(27), 3873-3883. http://dx.doi.org/10.1016/ S1352-2310(03)00343-1.

Beauchamp, E. G., Kidd, G. E., \& Thurtell, G. (1982). Ammonia volatilization from liquid dairy cattle manure in the field. Canadian J. Soil Sci., 62(1), 11-19. http://dx.doi.org/ 10.4141/cjss82-002.

Bjorneberg, D. L., Leytem, A. B., Westermann, D. T., Griffiths, P. R., Shao, L., \& Pollard, M. J. (2009). Measurement of atmospheric ammonia, methane, and nitrous oxide at a concentrated dairy production facility in southern Idaho using open-path FTIR spectrometry. Trans. ASABE, 52(5), 17491756. http://dx.doi.org/10.13031/2013.29137.

Bluteau, C. V., Massé, D. I., \& Leduc, R. (2009). Ammonia emission rates from dairy livestock buildings in eastern Canada. Biosystems Eng., 103(4), 480-488. http://dx.doi.org/ 10.1016/j.biosystemseng.2009.04.016.

Bonifacio, H. F., Maghirang, R. G., Razote, E. B., Trabue, S. L., \& Prueger, J. H. (2013). Comparison of AERMOD and WindTrax dispersion models in determining $\mathrm{PM}_{10}$ emission rates from a beef cattle feedlot. J. Air and Waste Mgmt. Assoc., 63(5), 545-556. http://dx.doi.org/10.1080/10962247.2013. 768311.

Cassel, T., Ashbaugh, L., \& Flocchini, R. (2005). Ammonia emission factors for open-lot dairies: Direct measurements and estimation by nitrogen intake. J. Air and Waste Mgmt. Assoc., 55(6), 826-833.

Chow, J. C., Watson, J. G., Lowenthal, D. H., Solomon, P. A., Magliano, K. L., Ziman, S. D., \& Richards, L. W. (1993). $\mathrm{PM}_{10}$ and $\mathrm{PM}_{2.5}$ compositions in California's San Joaquin Valley. Aerosol Sci. Tech., 18(2), 105-128. http://dx.doi.org/ 10.1080/02786829308959588.

Cimorelli, A. J., Perry, S. G., Venkatram, A., Weil, J. C., Paine, R. J., Wilson, R. B., Lee, R. F., Peters, W. D., \& Brode, R. W. (2005). AERMOD: A dispersion model for industrial source applications: Part I. General model formulation and boundary layer characterization. J. Appl. Meteorol., 44(5), 682-693. http://dx.doi.org/10.1175/JAM2227.1. 
Cole, N. A., Clark, R. N., Todd, R. W., Richardson, C. R., Gueye, A., Greene, L. W., \& McBride, K. (2005). Influence of dietary crude protein concentration on potential ammonia emissions from beef cattle manure. J. Animal Sci., 83(3), 722-731.

Davidson, C. I., Phalen, R. F., \& Solomon, P. A. (2005). Airborne particulate matter and human health: A review. Aerosol Sci. and Tech., 39(8), 737-749. http://dx.doi.org/10.1080/ 02786820500191348.

Duce, R. A. (1991). The atmospheric input of trace species to the world's ocean. Global Biogeochem. Cycles, 5(3), 193-259. http://dx.doi.org/10.1029/91GB01778.

EPA. (2001). National pollutant discharge elimination system permit regulation and effluent limitation guidelines and standards for concentration animal feeding operations. Fed. Register, 66(9), 2960-3138.

EPA. (2003). National air quality and emissions trends report: 2003 special studies edition. EPA-454/R-03-005. Research Triangle Park, N.C.: U.S. EPA, Office of Air Quality Planning and Standards.

EPA. (2005). National emission inventory: Ammonia emissions from animal agricultural operations. Revised draft report. Washington, D.C. Retrieved from: ftp://ftp.epa.gov/Emis Inventory/2002finalnei/documentation/nonpoint/nh3inventory draft_042205.pdf.

EPĀ. (2008). AERSURFACE user's guide. EPA-454/B-08-001. Research Triangle Park, N.C.: U.S. EPA, Office of Air Quality Planning and Standards.

Faulkner, W. B., Lange, J. M., Powell, J. J., Shaw, B. W., \& Parnell, C. B. (2007). Sampler placement to determine emission factors from ground-level area sources. Atmos. Environ., 41(35), 7672-7678. http://dx.doi.org/10.1016/ j.atmosenv.2007.08.029.

Faulkner, W. B., Shaw, B. W., \& Grosch, T. (2008). Sensitivity of two dispersion models (AERMOD and ISCST3) to input parameters for a rural ground-level area source. J. Air and Waste Mgmt. Assoc., 58(10), 1288-1296. http://dx.doi.org/ 10.3155/1047-3289.58.10.1288.

Flesch, T. K., Harper, L. A., Powell, J. M., \& Wilson, J. D. (2009a). Inverse-dispersion calculation of ammonia emissions from Wisconsin dairy farms. Trans. ASABE, 52(1), 253-265. http://dx.doi.org/10.13031/2013.25946.

Flesch, T. K., Harper, L. A., Desjardins, R. L., Gao, A., \& Crenna, B. P. (2009b). Multi-source emission determination using an inverse-dispersion technique. Boundary Layer Meteorol., 132(1), 11-30. http://dx.doi.org/10.1007/s10546-009-9387-1.

Going, C., Bingham, G. B., Pougatchev, N. S., Day, E., Moore, K., Martin, R., \& Reese, E. (2008). Multipath FTIR agricultural air pollution measurement system. ASABE Paper No. 084080. St. Joseph, Mich.: ASABE.

Griffiths, P. R., Shao, L., \& Leytem, A. B. (2009). Completely automated open-path FT-IR spectrometry. Anal. and Bioanal. Chem., 393(1), 45-50. http://dx.doi.org/10.1007/s00216-0082429-6.

Hansen, F. V. (1993). Albedos. ARL-TR-5. Adelphi, Md.: U.S. Army Research Laboratory. Retrieved from: www.dtic.mil/ cgi-bin/GetTRDoc?AD=ADA268255.

Leytem, A. B., Dungan, R. S., \& Bjorneberg, D. L. (2009). Case study: Seasonal and spatial distribution of ambient ammonia concentrations measured at a large open-lot dairy. Prof. Animal Sci., 25(6), 786-793.

Leytem, A. B., Dungan, R. S., Bjorneberg, D. L., \& Koehn, A. C. (2010). Emissions of ammonia, methane, carbon dioxide, and nitrous oxide from dairy cattle housing and manure management systems. J. Environ. Qual., 40(5), 1383-1394. http://dx.doi.org/10.2134/jeq2009.0515.
Leytem, A. B., Dungan, R. S., Bjorneberg, D. L., \& Koehn, A. C. (2013). Greenhouse gas and ammonia emissions from an openfreestall dairy in southern Idaho. J. Environ. Qual., 42(1), 1020. http://dx.doi.org/10.2134/jeq2012.0106.

Marchant, C. C., Moore, K. D., Wojcik, M. D., Martin, R. S., Pfeiffer, R. L., Prueger, J. H., \& Hatfield, J. L. (2011). Estimation of dairy particulate matter emission rates by lidar and inverse modeling. Trans. ASABE, 54(4), 1453-1463. http://dx.doi.org/10.13031/2013.39026.

Meng, Z. Y., Lin, W. L., Jiang, X. M., Yan, P., Wang, Y., Zhang, Y. M., Jia, M. X., \& Yu, X. L. (2011). Characteristics of atmospheric ammonia over Beijing, China. Atmos. Chem. Physics, 11(12), 6139-6151. http://dx.doi.org/10.5194/acp-116139-2011.

Moore, K. D. (2007). Derivation of agricultural gas-phase ammonia emissions and application to the Cache Valley. MS thesis. Logan, Utah: Utah State University, Department of Civil and Environmental Engineering.

Mukhtar, S., Mutlu, A., Capareda, S. C., \& Parnell, C. B. (2008). Seasonal and spatial variations of ammonia emissions from an open-lot dairy operation. J. Air and Waste Mgmt. Assoc., 58(3), 369-376. http://dx.doi.org/10.3155/1047-3289.58.3.369.

Nennich, T. D., Harrison, J. H., VanWieringen, L. M., Meyer, D., Heinrichs, A. J., Weiss, W. P., St-Pierre, N. R., Kincaid, R. L., Davidson, D. L., \& Block, E. (2005). Prediction of manure and nutrient excretion from dairy cattle. J. Dairy Sci., 88(10), 3721-3733. http://dx.doi.org/ 10.3168/jds.S0022-0302(05) 73058-7.

Ngwabie, N. M., Jeppsson, K.-H., Nimmermark, S., Swensson, C., \& Gustafsson, G. (2009). Multi-location measurements of greenhouse gasses and emission rates of methane and ammonia from a naturally ventilated barn for dairy cows. Biosystems Eng., 103(1), 68-77. http://dx.doi.org/10.1016/ j.biosystemseng.2009.02.004.

Paerl, H. W. (1985). Enhancement of marine primary productivity by nitrogen enriched rain. Nature, 315(6022), 747-749. http://dx.doi.org/10.1038/315747a0.

Puchalski, M. A., Sather, M. E., Walker, J. T., Lehmann, C. M., Gay, D. A., Mathew, J., \& Robarge, W. P. (2011). Passive ammonia monitoring in the United States: Comparing three different sampling devices. J. Environ. Monit., 13(11), 31563167. http://dx.doi.org/10.1039/c1em10553a.

Roadman, M. J., Scudlark, J. R., Meisinger, J. J., \& Ullman, W. J. (2003). Validation of Ogawa passive samplers for the determination of gaseous ammonia concentrations in agricultural settings. Atmos. Environ, 37(17), 2317-2325. http://dx.doi.org/10.1016/S1352-2310(03)00163-8.

Robarge, W. P., Walker, J. T., McCulloch, R. B., \& Murray, G. (2002). Atmospheric concentrations of ammonia and ammonium at an agricultural site in the southeast United States. Atmos. Environ., 36(10), 1661-1674. http://dx.doi.org/ 10.1016/S1352-2310(02)00171-1.

Rumburg, B., Mount, G. H., Filipy, J., Lamb, B., Westberg, H., Yonge, D., Kincaid, R., \& Johnson, K. (2008a). Measurement and modeling of atmospheric flux of ammonia from dairy milking cow housing. Atmos. Environ., 42(14), 3364-3379. http://dx.doi.org/ 10.1016/j.atmosenv.2007.05.042.

Rumburg, B., Mount, G. H., Yonge, D., Lamb, B., Westberg, H., Neger, M., Filipy, J., Kincaid, R., \& Johnson, K. (2008b). Measurements and modeling of atmospheric flux of ammonia from an anaerobic dairy waste lagoon. Atmos. Environ., 42(14), 3380-3393. http://dx.doi.org/10.1016/j.atmosenv. 2007.02.046.

Schmidt, D. R., Jacobsen, L. D., \& Janni, K. A. (2002). Continuous monitoring of ammonia, hydrogen sulfide, and 
dust emissions from swine, dairy, and poultry barns. ASAE Paper No. 024060. St. Joseph, Mich.: ASAE.

Schrade, S., Zeyer, K., Gygax, L., Emmenegger, L., Hartung, E., \& Keck, M. (2012). Ammonia emissions and emission factors of naturally ventilated dairy housing with solid floors and an outdoor exercise area in Switzerland. Atmos. Environ., 47, 183-194. http://dx.doi.org/ 10.1016/j.atmosenv.2011.11.015.

Shao, L., Griffiths, P. R., \& Leytem, A. B. (2010). Advances in data processing for open-path Fourier transform infrared spectrometry of greenhouse gases. Anal. Chem., 82(19), 80278033. http://dx.doi.org/10.1021/ac101711r.

Sheffield, R. E., \& Louks, B. (2006). Diurnal variations of ammonia and hydrogen sulfide flux from a dairy manure storage pond in Idaho. In Proc. Workshop on Agricultural Air Quality: State of the Science, 1131-1135. V. P. Aneja et al., eds. Raleigh, N.C.: North Carolina State University, Department of Communication Services.

Siong, P., \& Sheikh, S. (2006). Conservation management practices program: Report for 2005. San Joaquin Valley Air Pollution Control District (SJVAPCD). Retrieved from: www.valleyair.org/farmpermits/updates/cmp_program report for 2005.pdf.

Smits, M. C., Valk, H., Elzing, A., \& Keen, A. (1995). Effect of protein nutrition on ammonia emission from a cubicle house for dairy cattle. Livestock Prod. Sci., 44(2), 147-156. http://dx.doi.org/10.1016/0301-6226(95)00068-6.
Sommer, S. G., Oleson, J. E., \& Christensen, B. T. (1991). Effects of temperature, wind speed, and air humidity on ammonia volatilization from surface applied cattle slurry. J. Agric. Sci., 117(1), 91-100. http://dx.doi.org/10.1017/S0021859600079016.

Sommer, S. G., Génermont, S., Cellier, P., Hutchings, N. J., Olesen, J. E., \& Morvan, T. (2003). Processes controlling ammonia emission from livestock slurry in the field. European J. Agron., 19(4), 465-486. http://dx.doi.org/ 10.1016/S11610301(03)00037-6.

Todd, R. W., Cole, N. A., Clark, R. N., Flesch, T. K., Harper, L. A., \& Baek, B. H. (2008). Ammonia emissions from a beef cattle feedyard on the southern High Plains. Atmos. Environ., 42, 6797-6805. http://dx.doi.org/10.1016/j.atmosenv. 2008.05.013.

USDA. (2009). 2007 Census of Agriculture: United States summary and state data. AC-07-A-51. Washington, D.C.: USDA.

Walker, J. T., Whitall, D. R., Robarge, W., Paerl, \& Paerl, H. W. (2004). Ambient ammonia and ammonium aerosol across a region of variable ammonia emission density. Atmos. Environ., 38(9), 1235-1246. http://dx.doi.org/10.1016/j.atmosenv. 2003.11.027.

Zhao, L. Y., Darr, M., Wang, X., Manuzuo, R., Brugger, M., Imerman, E., Arnold, G. , Keener, H., \& Heber, A. J. (2007). Temporal variations in gas and odor emissions from a dairy manure storage pond. In Proc. Sixth Intl. Dairy Housing Conf. St. Joseph, Mich.: ASABE. 